\title{
Working
}

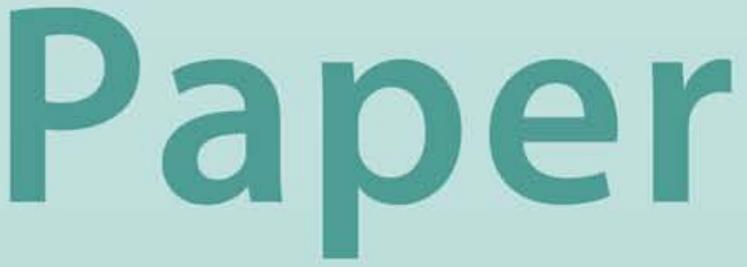




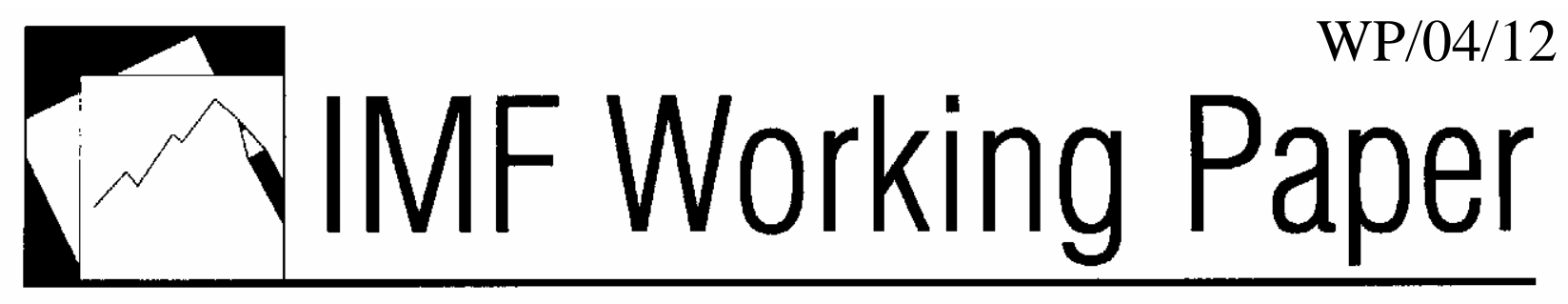

The Late 1990s Financial Crisis in Ecuador: Institutional Weaknesses, Fiscal Rigidities, and Financial Dollarization
at Work Luis I. Jacome H. 


\title{
IMF Working Paper
}

Monetary and Financial Systems Department

\section{The Late 1990s Financial Crisis in Ecuador: Institutional Weaknesses, Fiscal Rigidities, and Financial Dollarization at Work}

\author{
Prepared by Luis I. Jácome H. ${ }^{1}$ \\ Authorized for distribution by Mark Swinburne
}

January 2004

\begin{abstract}
This Working Paper should not be reported as representing the views of the IMF.

The views expressed in this Working Paper are those of the author(s) and do not necessarily represent those of the IMF or IMF policy. Working Papers describe research in progress by the author(s) and are published to elicit comments and to further debate.
\end{abstract}

This paper stresses three factors that amplified the 1990s financial crisis in Ecuador, namely institutional weaknesses, rigidities in public finances, and high financial dollarization.

Institutional factors restricted the government's ability to respond in a timely manner and efficiently enough to prevent the escalation of the banking crisis and spurred the adoption of suboptimal policy decisions. Public finance rigidities limited the government's capacity to correct existing imbalances and the deteriorating fiscal stance associated with the costs of the financial crisis. Financial dollarization increasingly reduced the effectiveness of financial safety nets, fostered foreign currency demand, and accelerated a currency crisis, thereby further worsening the solvency of banks. These three factors reinforced each other, exacerbating costs as the economy went through a triple banking, currency, and fiscal crisis.

JEL Classification Numbers: G21, G28, N46, O54

Keywords: banking crisis, institutions, fiscal policy, monetary policy, dollarization, blanket guarantee

Author’s E-Mail Address: liacome@imf.org

\footnotetext{
${ }^{1}$ I thank, without implicating, María Caridad Araujo, Jorge Cayazzo, Carlos Cobo, Augusto de la Torre, Stefan Ingves, Jens Nystedt, Marc Quintyn, Bob Traa, Marco Varea, Mauricio Villafuerte, Delisle Worrell, Mayra Zermeño, and participants in the seminar in the IMF's Monetary and Financial Systems Department.
} 
I. Introduction

II. Roots of the Banking Crisis

A. Relevant Macroeconomic Trends During the 1990s............................................... $\frac{6}{7}$

Reduced Margin for Conducting Fiscal Policy........................................... $\frac{7}{0}$

Monetary Policy Downfall and Increasing Dollarization ..............................10

B. Financial Liberalization and "Boom and Bust" Cycle .......................................12

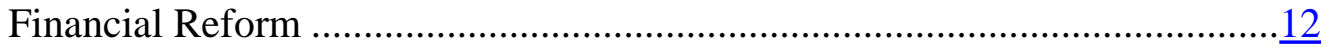

Credit Boom and Its Reversal .......................................................

III. A Stylized View of the Financial Crisis ............................................................... 16

A. Outbreak of the Banking Crisis................................................................... $\frac{17}{17}$

B. "AGD Law" and Conflicting Effects of the Blanket Deposit Guarantee and the Financial Transaction Tax............................................................................. 19

C. Currency Crisis and Bank Deposits' Freeze ...................................................... $\frac{20}{22}$

D. Unfreezing of Deposits and the Banking and Monetary Collapse ..........................

IV. Exacerbating Effects of Institutional Weaknesses, Fiscal Rigidities, and Financial

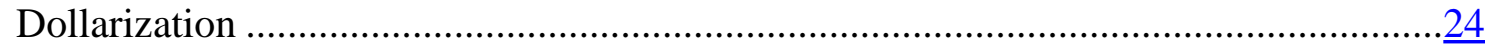

A. Restrictive Institutional Weaknesses ...................................................... $\frac{25}{28}$

B. Impact of Fiscal Policy Rigidities and Financial Transaction Tax ...................... $\frac{28}{30}$

C. Role of Financial Dollarization ......................................................................

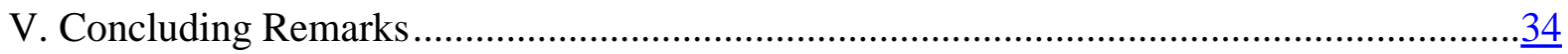

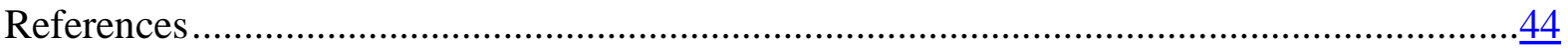

Appendix

Institutional Weaknesses and the Financial Sector ......................................................

Appendix Boxes

1. Ecuador's Geographic, Ethnic, Political, and Economic Fragmentation........................... $\underline{38}$

2. Recent History of Private Sector and Bank Bailouts Using Public Funds ........................

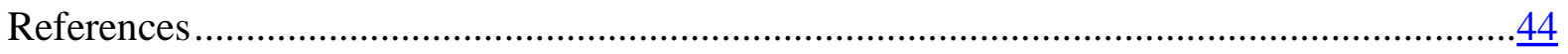

Figures

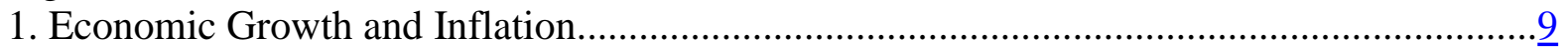

2. Macroeconomic Imbalances and Oil Price ................................................................. $\underline{9}$

3. Government Revenues and International Oil Prices .................................................... $\frac{9}{9}$

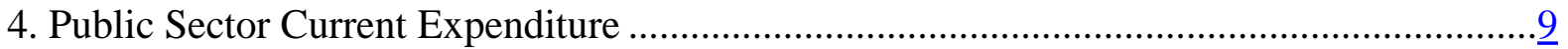

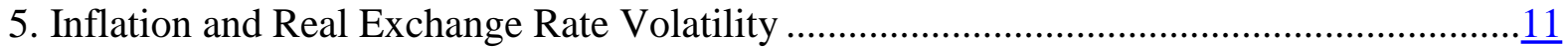

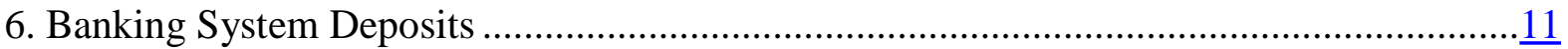

7. Sucre and Dollar-Equivalent Lending Interest Rate ............................................. 
8. Banking System Credit ...................................................................................

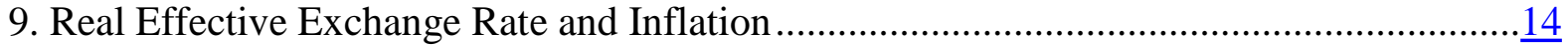

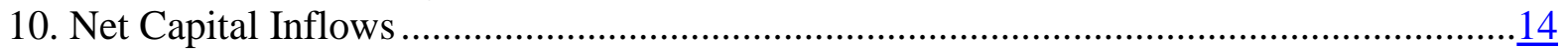

11. Net International Reserves and Interest Rates ....................................................14

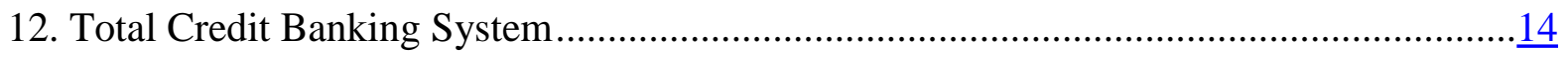

13. Banks' Liquidity and Credit Crunch................................................................ 18

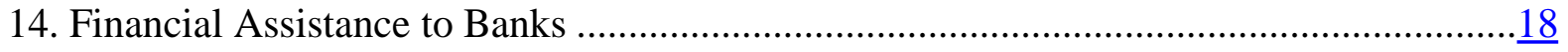

15. Total Deposits and Currency Issue ................................................................... $\frac{18}{18}$

16. Open-Market Operations ............................................................................

17. Net International Reserves and Nominal Exchange Rate ........................................

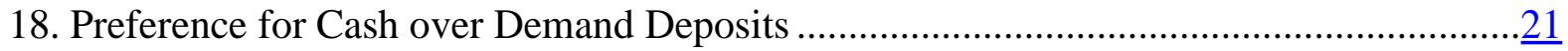

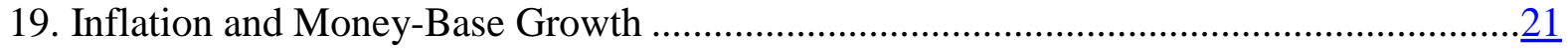

20. External and Internal Public Debt..................................................................... $\frac{31}{31}$

21. External Credit Lines and Country Risk .................................................................... $\frac{31}{31}$

22. Banks’ Dollar Deposits and Interest Rates ......................................................... $\frac{31}{31}$

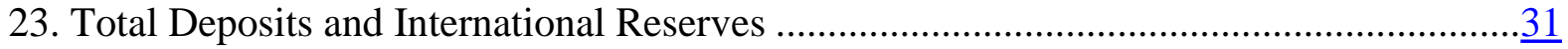

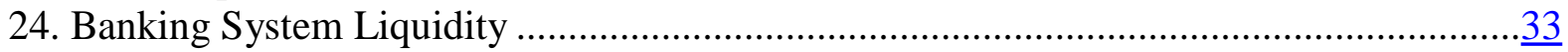

25. Dollar Loans and Share in Total Loans ............................................................. $\frac{33}{33}$

26. Open-Market Operations and Interest Paid............................................................. 33 
Ecuador's economic history has not been a happy one. A lack of national cohesion has dogged the country ever since it opted for independence from Simon Bolivar's Grancolombian Federation in 1830. From the start there was fierce rivalry between the residents of the highlands, centered on the capital Quito, and those on the coast, centered in Guayaquil. Fortunately, though, these rivalries did not lead to violent confrontation, and Ecuador's history, although turbulent, has been peaceful. However, the deep split between the interests of the coastal and highlands regions has at times-and certainly during the last five years-made it almost impossible for the government to pursue a coherent economic policy.

Stanley Fischer (2001)

\section{INTRODUCTION}

The main goal of this study is to stress the importance of institutional weaknesses, public finance rigidities, and high financial dollarization in shaping the dynamics of the late-1990s financial crisis in Ecuador. ${ }^{2}$ The paper covers the crisis period up to the point when the government adopted the U.S. dollar as the legal tender, which marked a turnaround of the financial crisis. As an externality, the paper also aims at contributing to a better understanding of this crisis, which has so far received little attention in the literature. In particular, this paper argues that institutional weaknesses in Ecuador laid the groundwork for the increasing fragility of the banking system during the 1990s; and when the crisis erupted, institutional weaknesses worked as a crisis amplifier by leading to the adoption of suboptimal banking-resolution decisions. Public finance rigidities inhibited the adjustment that was necessary to align the fiscal stance with a deteriorating banking and currency trend, whereas taxing financial transactions accelerated the collapse of a number of financial institutions. In turn, financial dollarization undermined the effectiveness of financial safety nets and hastened a currency crisis, thereby further worsening the solvency of banks. ${ }^{3}$ These three factors reinforced each other, exacerbating the cost of the crisis as the economy went through a simultaneous banking, currency, and fiscal crisis.

In the late 1990s, Ecuador suffered its worst economic crisis. The 1999 economic downturn was the steepest, and the following year inflation hit record highs. The underlying cause of

\footnotetext{
${ }^{2}$ In this paper, the term "institutions" refers to organizational and regulatory aspects underpinning government decisions-in the present case, those relevant to the functioning of the financial system. Public finance rigidities refer to the government's limited ability to increase revenues and cut expenditures and to their difficulties in accessing capital markets in order to finance fiscal gaps. Financial dollarization refers to the extensive use of a foreign currency - in this case, the U.S. dollar - to value assets and liabilities in the financial system, while real sector transactions are mostly denominated in domestic currency.

${ }^{3}$ The study is not meant to convey the message that financial dollarization per se is necessarily negative. Recognizing that financial dollarization creates benefits, in particular in inflationary economies, since it allows countries to maintain financial depth (see De Nicoló, Honohan, and Ize, 2003), the paper claims that during periods of financial turbulence, financial dollarization adds a negative dynamic to banking crises, complicating their management and making the country more prone to a simultaneous currency crash (see Ingves and Moretti, 2003).
} 
the upheaval was the collapse of the banking system, which was accompanied by a simultaneous currency and public finance crisis. The crisis involved 16 banks-out of the 40 existing in 1997 - and was triggered by a combination of exogenous and policy-induced shocks which led the market to lose confidence in both the banking system and the domestic currency, while government liabilities increased dramatically until the country defaulted on its recently restructured Brady debt. On the brink of hyperinflation and immersed in a deep macrofinancial crisis, the government adopted the U.S. dollar as legal tender as a substitute to the sucre in January 2000. Today, the economy has stabilized and the financial system has recovered, although by the end of 2002 the country's degree of financial intermediation had not yet returned to its pre-crisis level.

The crisis exacted a grievous economic toll, pushing the 1999 per capita gross domestic product (GDP) measured in real sucres down to 1977 levels. Preliminary estimates by Hoelscher and Quintyn (2003) put the cost of the financial crisis at over 20 percent of GDP. On an international scale, the cost of Ecuador's crisis is comparable to the most virulent financial storms weathered elsewhere in the region, like those experienced in the Southern Cone in the early 1980s and Mexico and Venezuela in the mid-1990s, and the more recent Argentine and Uruguayan crises.

As the economy neared collapse, Ecuadorans lived through painful episodes associated with the rapid depreciation of the sucre; the acceleration of inflation, and, in particular, the widespread freeze of bank deposits and the traumatic closure of financial institutions. Many depositors had to wait years to get their money back, which in most cases were recovered with a "haircut" owing to macroeconomic and regulatory reasons. The destruction of wealth in the wake of the crisis and the concomitant loss of jobs set off the largest emigration wave in Ecuador's history. ${ }^{4}$ The financial and social debacle played out amidst accusations of corruption, which triggered increasing social unrest, undermined the government's credibility, and ultimately saw President Jamil Mahuad replaced in January 2000.

Despite its devastating effects, extensive analysis of the Ecuadoran financial crisis has not been carried out, probably because of Ecuador's relatively low importance among emerging countries. ${ }^{5}$ The few existing studies have focused on financial aspects, with only marginal interest shown in the fiscal issues underlying the banking and currency crises, and with little attention paid to the link between the institutional setting and the management of the banking crisis and its aftermath. ${ }^{6}$ Nonetheless, the analysis of these caveats is germane, since political

\footnotetext{
${ }^{4}$ According to the results of the National Survey performed by National Institute of Statistics and Surveys (INEC), during 1999-2001, about 300,000 Ecuadorans (mostly workers) left the country. Other studies estimate that migration totaled 500,000 persons between 1998 and 2002. In any case, these are significant numbers in a country of less than 13 million inhabitants.

${ }^{5}$ Only de la Torre, García, and Mascaró (2002) and Beckerman (2002) studied the Ecuadoran banking crisis, although focusing exclusively on the macro financial aspects of the crisis.
} 
and economic decision making in Ecuador does not seem to be independent of institutional arrangements. ${ }^{7}$

In general, although banking crises have been extensively analyzed in the literature, the restrictions and effects imposed by institutional constraints, fiscal rigidities, and financial dollarization have so far attracted only slight attention. ${ }^{8}$ Among the few existing studies, institutional constraints and regulatory governance have been examined by Das and Quintyn (2002); and, at the country level, in the analysis of the Indonesian crisis (see, for example, Enoch and others, 2001). Hemming, Kell, and Schimmelpfenning (2003) highlight fiscal restrictions to some extent. In turn, dollarization has been subject of a novel interest since it has been addressed, to some extent, in Collyns and Kincaid (2003); Hoelscher and Quintyn (2003); and, in particular, by Ingves and Moretti (2003).

The structure of this paper is as follows. Section II identifies the roots of the financial crisis. Section III provides a snapshot of the dynamics of the crisis up to the adoption of the U.S. dollar as the legal tender, which marked a turnaround of the crisis. Section IV stresses the amplifying role of institutional weaknesses, fiscal rigidities, and financial dollarization. Section V extracts the main conclusions and applies them to the current state of play. The appendix expands the discussion about the legal and institutional weaknesses featuring the financial system in Ecuador prior to the late-1990s financial crisis.

\section{RoOTS OF THE BANKING CRISIS}

\section{A. Relevant Macroeconomic Trends During the 1990s}

Prior to the eruption of the crisis in 1998, Ecuador's economy had been growing slowly and inflation, albeit down from a few years earlier, was still relatively high. Real GDP growth averaged just over 3.5 percent-less than 1 percent annually in per capita terms-between 1990 and 1997, fueled by an increase in exports that doubled over the same interval. Ecuador had put in place a series of structural reforms during the early 1990s, which were aimed at underpinning short-term macroeconomic policies. As a result, greater macroeconomic stability was achieved during the 1993-95 period as average annual inflation came close to 40 percent during those years, having bottomed out at 22 percent in 1995 only to climb back to 30 percent by the end of 1997 and reach more than 50 percent by end-1999 (Figure 1).

\footnotetext{
${ }^{6}$ For an analysis of the institutional setting relevant to the financial system in Ecuador see de la Torre (1997) in relation to the mid-1990s banking problems and Patiño (2001) with respect to the late 1990s banking crisis.

${ }^{7}$ As examined by Hurtado (1997), the conduct of government policies in Ecuador has been historically driven by political and economic interest, which many times sought to defend or add privileges at the expense of the well being of the majority of the population.

${ }^{8}$ See the previous work by Sundararajan and Baliño (1991) on the 1970s and 1980s banking crises, Dress and Pazarbaşioğlu (1998) on the early 1990s Nordic banking crises, Hausmann and Rojas-Suárez (1996) on the mid1990s Latin American banking crises, and Lindgren and others (1999) on the Asian banking crises.
} 
The adverse exogenous shocks that hit the Ecuadoran economy by the middle of the decade and the country's increasing institutional instability, unveiled the government and central bank's limitations to preserve fiscal discipline and monetary policy credibility. Foreign capital inflows to Ecuador had swelled in the early 1990s as part of the general trend that benefited all of Latin America, but also responded to the increasing macroeconomic stability and to the normalization of the country's relations with the international financial community. ${ }^{9}$ However, starting in the early 1995 and following a string of exogenous events (most notably the hostilities with Peru, domestic political problems, ${ }^{10}$ and the "tequila" effect), Ecuador experienced a stop and reversal of capital inflows, which triggered financial instability and dived the country into a period of economic stagnation, featuring increasing macroeconomic imbalances, in a great extent correlated with the evolution of the external oil price (Figure 2). In this environment, macroeconomic performance deteriorated during the second half of the decade creating conditions that contributed decisively to the late $1990 \mathrm{~s}$ financial crisis.

\section{Reduced Margin for Conducting Fiscal Policy}

Fiscal policy was a key limitation for achieving economic stability during the 1990s. Since the 1980s, one administration after another brought in fiscal adjustment policies, but typically they were followed by periods of spending relaxation, plunging the country into a vicious circle that generated uncertainty about governments' commitment to low inflation policies. ${ }^{11}$ Behind the scenes, institutional and policy rigidities restricted governments capacity to maintain discipline over expenditures and to generate additional revenues, hindering fiscal adjustment necessary to cope with recurrent adverse exogenous shocks. In an environment of failed stabilization attempts, a growing "adjustment fatigue" took root in vast sectors of the society over the second half of the 1990s making fiscal adjustment even more difficult.

Revenues featured a high volatility and trended down toward the second half of the 1990s associated to the chronic instability of oil prices in the world market. With revenues from oil exports representing approximately 25 to 30 percent of total revenues, this large proportion made for volatile government revenue inflows. ${ }^{12}$ To compensate the decreasing trend in revenues from oil exports, price increases in domestic oil products-mainly gasolines-were

\footnotetext{
${ }^{9}$ Ecuador had suspended payments on its external commercial debt back in 1987.

${ }^{10}$ Political confrontations prompted the resignation of the Vice President of the Republic, the leader of the government's stabilization policies and structural reforms, in a nation that was emerging from a lengthy inflationary period and has been traditionally opposed to structural reforms.

${ }^{11}$ Fiscal adjustment was adopted in the context of macroeconomic programs negotiated with the IMF-seven agreements between 1980 and 1997-aimed at improving the overall macroeconomic performance, and in particular to reduce inflation. However, only one of these agreements was successfully completed-in 1983.

12 The price of Ecuadoran oil exports had trended down such that by end-1990s it was less than the price prevailing during the mid-1970s in nominal terms.
} 
adopted, but they were insufficient to maintain stability of total fiscal revenue, in particular in 1998 at the onset of the banking crisis (Figure 3).

In turn, increasing public debt service and the mounting wage bill created upward pressures in government expenditure during the second half of the 1990s. The increase in public sector wages and public debt interest payments led total current expenditure to shore up almost three percentage points of GDP between 1994 and 1998. In addition, current expenditure was highly vulnerable to the exchange rate performance given that most of the public debt was denominated in dollars. As a result, interest payments relative to GDP boosted in 1999 following the steep real depreciation of the sucre, although this effect was partially offset as the exchange rate depreciation also depressed the wage bill share in GDP (Figure 4).

The extensive recourse to earmarking revenues imposed further rigidities to fiscal policy management. While earmarking flourished during the early 1970s — the beginning of the oil era-it continued growing to benefit a large number of autonomous and decentralized government entities and to some non-profit organizations. Increasing earmarking reflected the lobbying and influences of powerful groups (the army, public sector unions, local governments, and others) to secure permanent financing aside from budgetary allocation of resources. ${ }^{13}$ Thus, total revenues were earmarked over the 1990 s up to more than 50 percent, most of which was established at the constitutional level making difficult any legal reform. ${ }^{14}$

Against this background, the chances to finance a large fiscal gap stemming from real and financial shocks were slim as Ecuador enjoyed only limited access to international capital markets and the central bank was not allowed to finance the fiscal deficit. Following the 1987 debt default and despite the 1994 Brady bonds restructuring, Ecuador was able to access to international capital markets only once, in 1997. Thus, besides multilateral institutions, the only remaining source of government financing was the shallow domestic market, composed mainly by local financial institutions, which were ready to buy government securities denominated or indexed to foreign currency. As a result, the stock of domestic debt climbed from 2 to close to 20 percent of GDP between 1990 and 1998, and contributed to shore up total public debt to more than 90 percent of GDP in 1998.

\footnotetext{
${ }^{13}$ Earmarking from tax revenues has been more transparent than that from oil revenues, which were built on a complex system where the distribution of resources among earmarking participants was influenced by the performance of oil export prices and the exchange rate, and by changes in domestic oil prices.

14 The main provision of earmarking stems from the 1978 Constitution, which established the allocation of 30 percent of government revenues for educational purposes. The 1998 Constitution also allocated 15 percent of government revenues to local governments without establishing the associated spending responsibilities.
} 


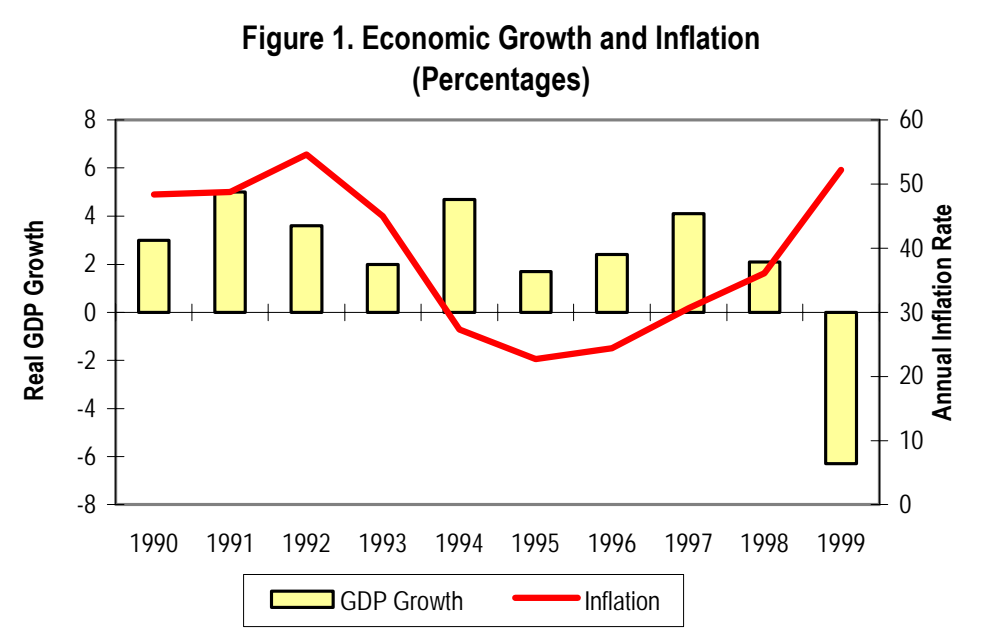

Source: Central Bank of Ecuador

Figure 3. Government Revenues and International Oil Prices

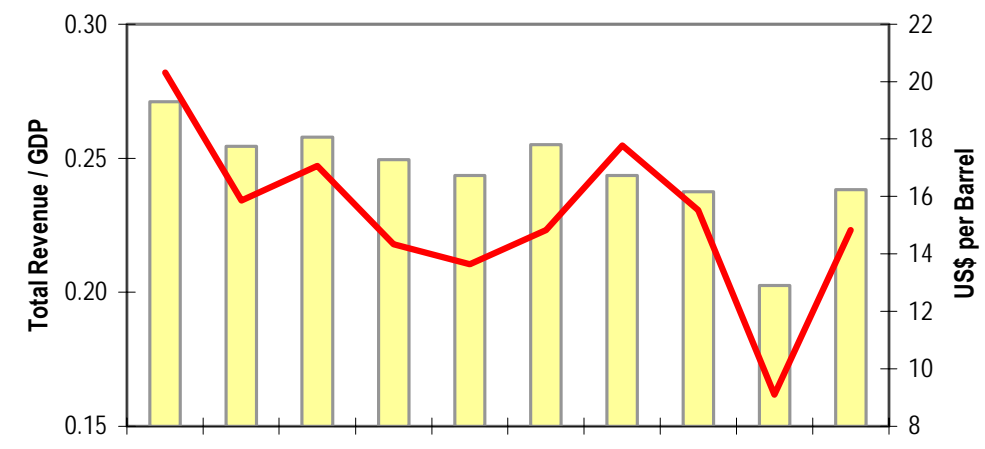

$\begin{array}{llllllllll}1990 & 1991 & 1992 & 1993 & 1994 & 1995 & 1996 & 1997 & 1998 & 1999\end{array}$

$$
\square \text { Total Rev. / GDP } \quad \text { Oil Price }
$$

Source: Central Bank of Ecuador
Figure 2. Macroeconomic Imbalances and Oil Price

(Percentages and US dollars per barrel)

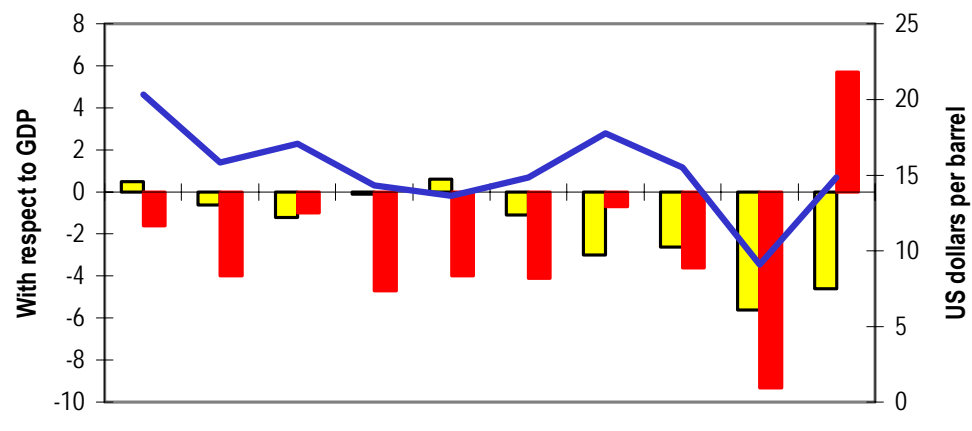

$\begin{array}{llllllllll}1990 & 1991 & 1992 & 1993 & 1994 & 1995 & 1996 & 1997 & 1998 & 1999\end{array}$

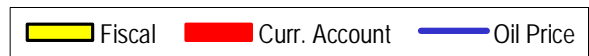

Source: Central Bank of Ecuador

Figure 4. Public Sector Current Expenditure (Percent of GDP)

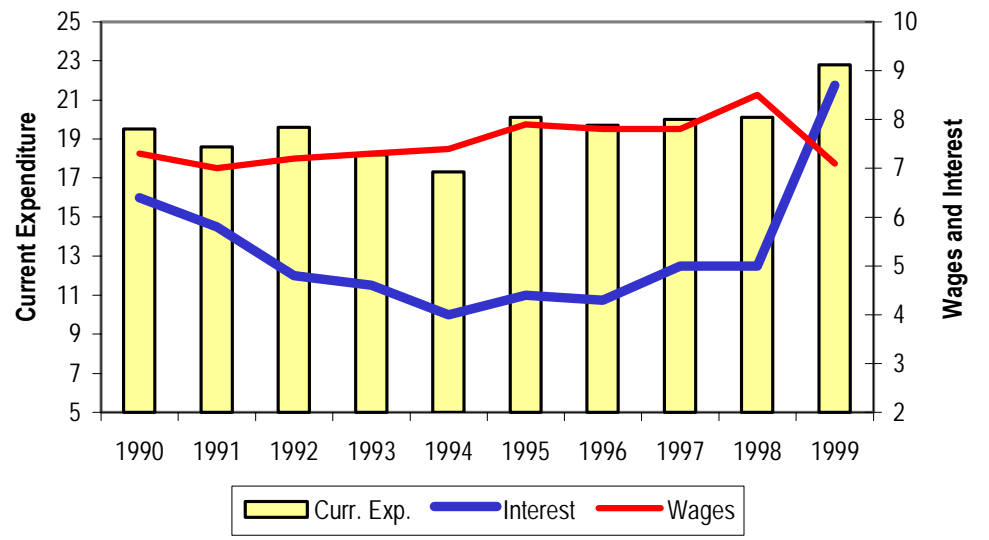

Source: Central Bank of Ecuador 


\section{Monetary Policy Downfall and Increasing Dollarization}

Simultaneously, from the mid-1990s onward, monetary policy was progressively less effective to defeat inflation. Ecuador adopted in late 1992 an exchange rate based stabilization program aimed at reducing a sticky 50 percent annual inflation rate. The exchange regime was initially based on a dirty float, but in 1994 the Central Bank of Ecuador (CBE) changed it to a preannounced crawling band with the aim of driving market expectations toward a downward trend in inflation. Nonetheless, the adoption of several adjustments to the parameters of the exchange rate band (six between 1995 and 1998), invalidated in most cases the initial commitments producing time inconsistency problems. Eventually, the credibility in the exchange regime steadily eroded, leaving the CBE without a nominal anchor for the pursuit of price stability.

As the sucre continued depreciating and inflation soared in the second half of the 1990s, markets increasingly lost credibility in the central bank policy targets, shifting financial assets to foreign currencies as a means of hedging against inflation. Increasing financial dollarization in Ecuador was an endogenous process encouraged by the higher volatility of inflation vis-à-vis the real exchange rate (Figure 5). ${ }^{15}$ It was facilitated by the proliferation of offshore branches, which paid higher deposit rates in the absence of reserve requirements and provided an expanded supply of financial services that facilitated portfolio reallocations from sucres to dollars. By end-1997, foreign currency deposits had climbed to over one third of total onshore deposits in the banking system and to more than 70 percent of CBE's net international reserves (Figure 6). Including deposits held in the offshore, total foreign currency deposits made up roughly two thirds of the system deposits, exceeding the amount of CBE's net international reserves. By contrast, the vast majority of transactions and wages were paid in sucres, although some contracts had been already indexed to U.S. dollarsmainly for renting or buying machinery, durable goods, and real state.

In an environment of lax prudential supervision, swift dollarization posed a serious risk to the precarious stability of the financial system in the event of a large devaluation. In addition to the typical currency risk associated to currency mismatches in bank balances, credit risk would emerge in the event of a large devaluation given that there was no regulation in place in Ecuador that precluded banks to grant foreign currency loans to local currency earners. As a result, borrowing in foreign currency rapidly increased, in particular from 1995 onwards, encouraged by the prevalence of lower dollar-equivalent interest rate compared to sucre interest rates (Figure 7). Thus, the lending boom grew stronger in foreign currency exceeding the value of sucre loans by mid-1998, before the banking crisis and the associated real exchange rate depreciation materialized (Figure 8).

\footnotetext{
${ }^{15}$ This seems to be an empirical regularity in financially dollarized economies (see Ize and Levy-Yeyati, 2003, and De Nicoló, Honohan, and Ize, 2003).
} 
Figure 5. Inflation and Real Exchange Rate Volatility (Monthly changes)

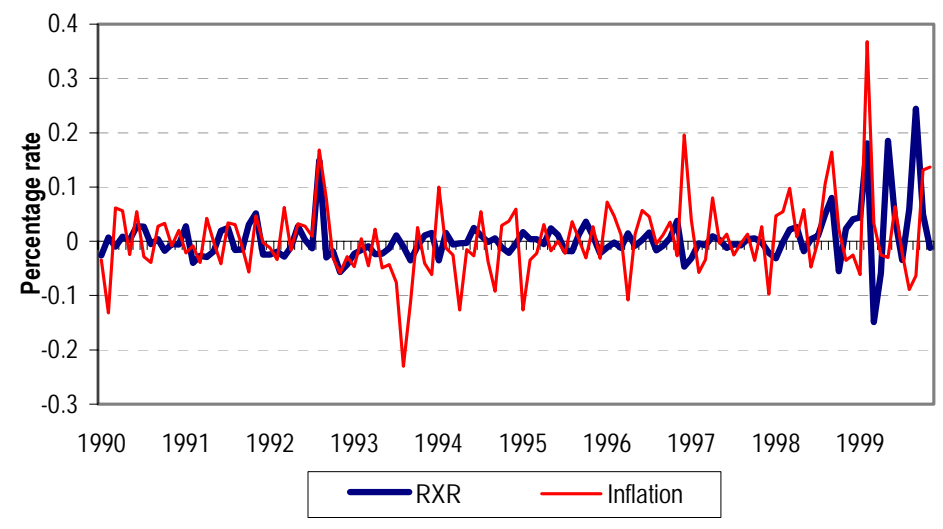

Source: Central Bank of Ecuador

Figure 7. Sucre and Dollar-Equivalent Lending Interest Rate

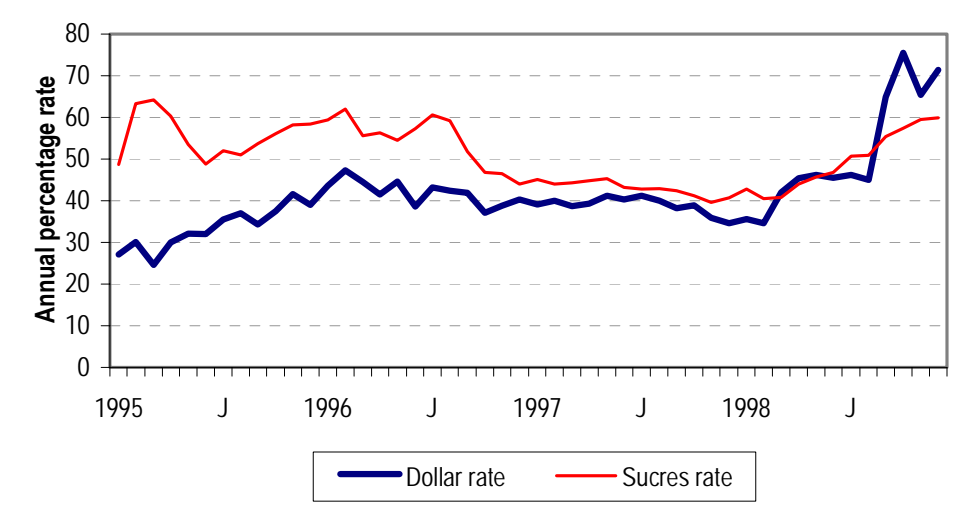

Source: Central Bank of Ecuador
Figure 6. Banking System Deposits (Trillions of sucres)

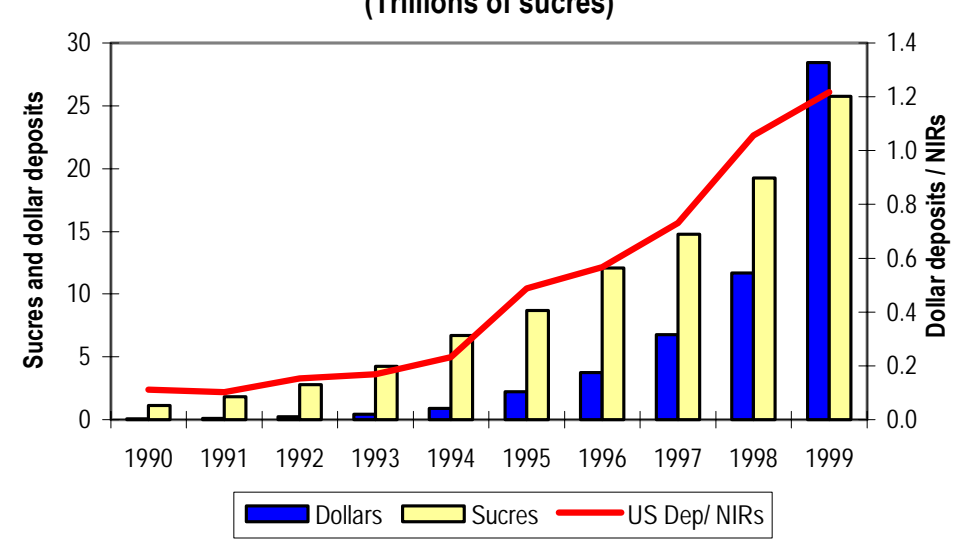

Source: Central Bank of Ecuador

Source: Central Bank of Ecuador 


\section{B. Financial Liberalization and "Boom and Bust" Cycle}

Ecuador's late 1990s banking crisis had much the same roots as similar episodes of systemic banking crises in other countries. It was the result of a "boom and bust" cycle that took place in the context of financial liberalization, coupled with lax financial surveillance and bad banking practices. Financial vulnerabilities engendered during the booming period but became evident and worsened following the sudden slowdown of economic activity in 1995 resulting from the adverse exogenous shocks that hit Ecuador early that year, and later as a result of the subsequent new round of negative external shocks in 1997 and 1998.

Toward 1993 and 1994, Ecuador's macroeconomic prospects looked promising. An exchange rate based stabilization program succeeded in reducing inflation, supported by a tight fiscal policy and market-oriented structural reforms. In the absence of capital account restrictions, capital inflows and a real exchange rate appreciation (20 percent during the period 1993-95) contributed to the success of central bank policies in lowering inflation up to late 1995 (Figure 9). Fiscal tightening contributed in this endeavor with an average 0.3 percent of GDP fiscal surplus in 1993 and 1994. This adjustment translated into an accumulation of deposits in the $\mathrm{CBE}$, mitigating — at least partially - the need for sterilizing the rapid re-monetization of the economy that took place during the stabilization period, thereby contributing to the downward trend in interest rates.

\section{Financial Reform}

The 1994 Law of the Financial System Institutions (LFSI) created the legal basis for financial liberalization as a means of enhancing financial intermediation and improving investment allocation. This legislation complemented the reform of the CBE charter in 1992, which liberalized interest rate policy and put in place a more flexible exchange rate regime. ${ }^{16}$ The reform of the central bank law allowed monetary policy to focus in defeating inflation and promoted the use of indirect instruments of monetary policy. Deregulation and market-based monetary policies spurred an active money market and a dynamic interbank foreign currency market.

Despite recurrent banking problems and the toll they took on economic performance during the 1980s, the reform did not establish compatible incentives for financial market participants. Market players continued interacting in an environment of relaxed market discipline, encouraged by moral hazard stemming from successive bailouts granted over the 1980s (see Box 2 in the Appendix). ${ }^{17}$ The reform did not encourage depositors and bank

\footnotetext{
${ }^{16} \mathrm{Up}$ to that year, the $\mathrm{CBE}$ had capped financial intermediation interest rate spreads and banks had to surrender foreign exchange to the $\mathrm{CBE}$ under a preannounced crawling peg system.

${ }^{17}$ As an example, the CBE absorbed commercial banks' foreign currency obligations and simultaneously converted into sucres its claims on commercial banks, thereby preventing an incipient banking crisis in 1983. Since the new domestic currency debt was restructured at below market conditions, the CBE amassed huge losses, which were not compensated by the government (see Samaniego and Villafuerte, 1997)
} 
administrators/shareholders to minimize risks, since they relied on-potentially largecentral bank monetary support to assist banks under liquidity and solvency shortages. In turn, banking authorities and the government counted on central bank resources to finance bank resolution in the event of a financial crisis.

Financial liberalization promoted free entry and exit of institutions to the financial market and leveled the playing field between domestic and foreign banks. The number of financial institutions boosted as banks increased from 31 in 1993 to 44 in 1996, although foreignbased banks did not multiply despite the stimulus introduced in the new legislation. ${ }^{18}$ Simultaneously, bank operations expanded, in particular in foreign currency, encouraged by the parallel surge of offshore branches. Despite the dynamic expansion of the financial industry, the Superintendence of Banks and Insurance Companies (SBS) failed to heighten prudential supervision as it would have been desirable in a more liberalized environment.

Probably the main caveat of the new legislation was the ineffectual consolidated supervision that, for all practical purposes, failed to effectively monitor offshore branches. Consolidated supervision provided scant information, or at best, supplied information with a lag, and hence, offshore branches never came under full control of the SBS. The lack of an effective comprehensive surveillance opened the door for practices that allowed banks to circumvent regulations and controls. Under these conditions, banking authorities could not obtain an accurate assessment of the financial system soundness, and in the event of a banking crisis they were likely to encounter significant shortcomings, in particular, should liquidity runs involved offshore branches.

In addition, the new financial legislation did not create the legal basis for preventing bank's distress and crises. Financial surveillance relied on compliance-checking practices rather than on risk-oriented procedures (see Appendix I). The failure to monitor risk-taking was a serious shortcoming in an environment of financial liberalization, capital inflows-during the first half of the 1990s - and increasing dollarization, since financial intermediaries could engage on transactions that involved potential large exchange rate and credit risks.

The LFSI did not provide either appropriate instruments for bank resolution in the event that a banking crisis emerged. Transferring deposits from a failing bank to a sound financial institution was not allowed, and hence, bank resolution was invariably conducive either to contagion to other financial institutions - since the closure of a bank would imply that all depositors would suffer partial or total losses of their savings - or to an almost open-ended central bank emergence assistance. As a result, in any case bank resolution would lead to broad macroeconomic instability and potentially to a currency crash resulting from the high degree of financial dollarization.

\footnotetext{
${ }^{18}$ The number of finance companies - not authorized to take deposits but allowed to issue financial certificates_-also increased from 9 in 1992 to 45 in 1995.
} 
Figure 9. Real Effective Exchange Rate and Inflation

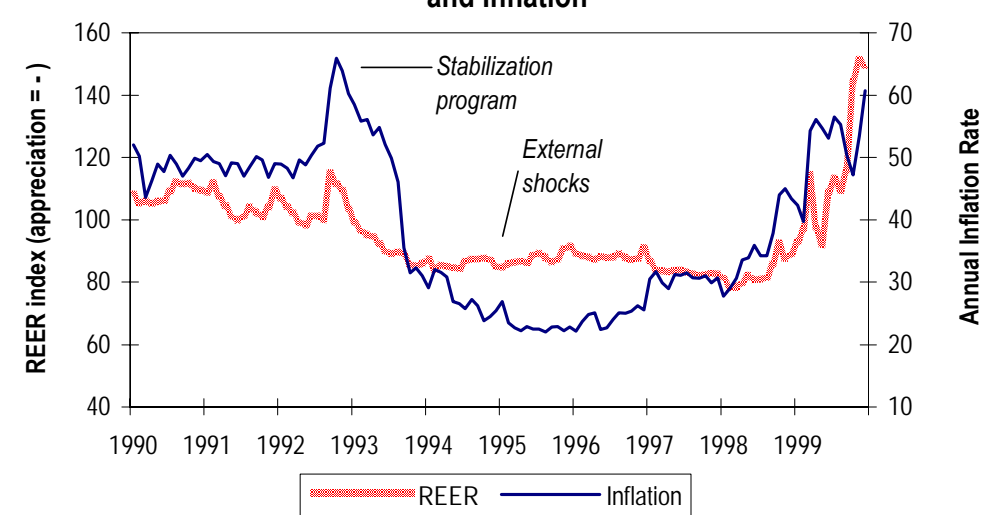

Source: Central Bank of Ecuador

Figure 11. Net International Reserves and Interest Rates (Millions of US dollars and annual rate)

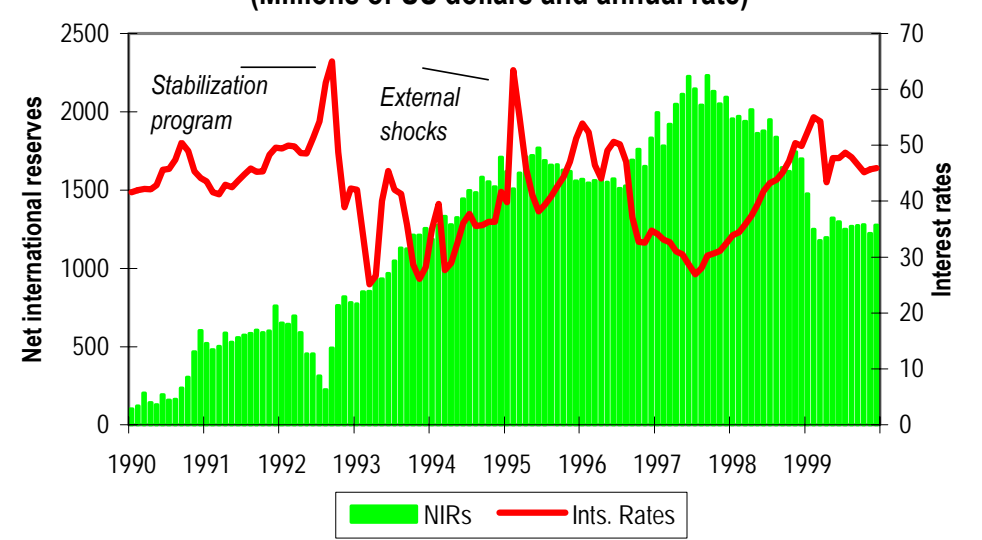

Source: Central Bank of Ecuador
Figure 10. Net Capital Inflows

(Excluding arrears)

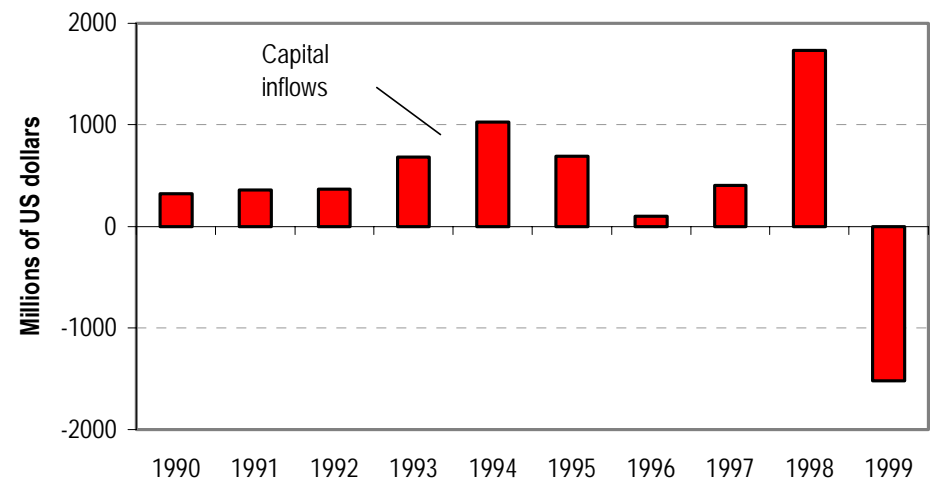

Source: Central Bank of Ecuador

Figure 12. Total Credit Banking System

(Real growth)

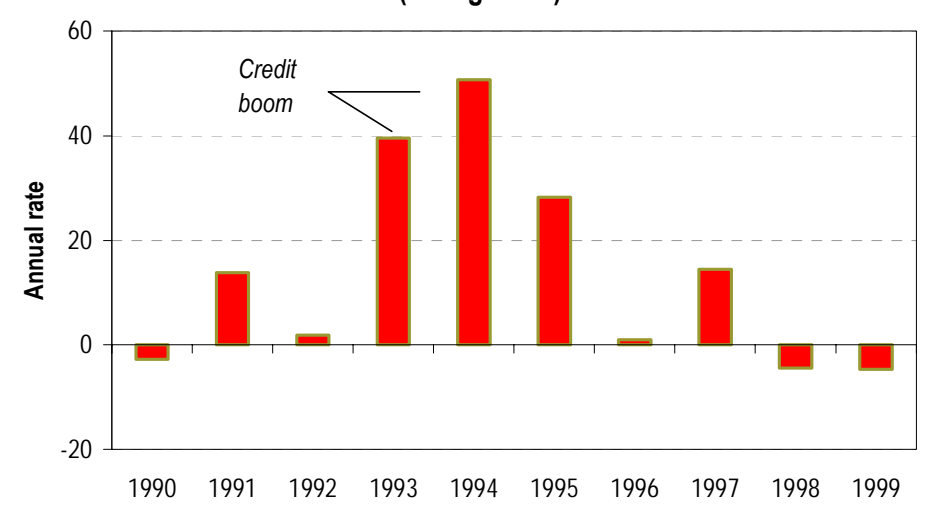

Source: Central Bank of Ecuador 
To mitigate the costs of potential bank failures Ecuador had put in place a financial safety net, but its design was conducive to macroeconomic instability and to create moral hazard. The CBE was legally assigned the role of LOLR. However, despite the persistent dollarization of deposits over the 1990s, the law would only allow the CBE to provide emergency assistance in domestic currency and not in dollars. In addition, the amount of emergency assistance was almost unlimited. Thus, large monetization would tend to impair macroeconomic stability, in particular when the troubled bank was a large institution. Likewise, there was a deposit guarantee in place to protect small depositors (up to US\$8,000 approximately), which relied on central bank funds to be effective, and hence, it also entailed adverse monetary effects. The excessive reliance of financial safety nets on central bank resources was seemingly part of the country's culture of bailing out private debtors and bank shareholders with central bank resources. ${ }^{19}$

Under this legal and institutional framework, financial intermediaries engaged into risky operations, including transactions in foreign currency mainly with offshore branches. Some of these transactions included asset-liability-maturity and currency-mismatches, connected lending, and even fraudulent operations. The most conspicuous case of bad banking as of mid-1990s was that of Banco Continental, which was seized by the CBE in 1996 after it succumbed to irreversible liquidity and solvency problems. ${ }^{20}$

\section{Credit Boom and Its Reversal}

Financial liberalization in Ecuador coincided with a period of foreign capital inflowspouring into the emerging economies - attracted by higher domestic returns in an environment of greater macroeconomic stability (Figure 10). As capital inflows multiplied, net international reserves in the CBE doubled between 1993 and 1995. As a result, interest rates began to trend down symmetrically to the increase in international reserves (Figure 11).

In turn, the rapid monetization of the economy brought in a sizable credit boom. Credit soared in real terms by 40 percent in 1993 and by 50 percent in 1994 (Figure 12). The increase in liquidity was also encouraged by the significant and rapid reduction of reserve requirements in 1994, from 28 to 10 percent for demand deposits in domestic currency and from 35 to 10 percent for deposits in foreign currency. As it is fairly common during periods of liquidity abundance and credit booms, and in particular in an environment of lax

\footnotetext{
${ }^{19}$ The latest of these events had taken place in 1988, when the Monetary Board required the CBE to buy external public debt at face value to commercial banks, although in the secondary market it was priced at a steep discount since Ecuador had defaulted on its external debt in 1987. Profits from these transactions would cancel commercial bank liabilities with the CBE, including reserve requirement shortages. Samaniego and Villafuerte (1997) calculate that the difference between the nominal and the face value of theses securities mounted to 2.4 percent of GDP and to more than total equity of the beneficiary institutions.

${ }^{20}$ Banco Central del Ecuador (1996) records a sequence of fraudulent operations committed by Banco Continental.
} 
prudential regulation, financial intermediaries failed to carefully gauge the risks embedded in their lending operations. For instance, some banks went onto the buoyant money market to borrow overnight and lent to their customers at higher rates and longer maturities. While these transactions had a high pay-off during periods of liquidity, they turned into a boomerang when a sudden liquidity shortage emerged such as the one that occurred in Ecuador in early 1995.

To cope with the stop and reversal of capital inflows stemming from the "Tequila crisis," the border conflict with Peru, and a number of other exogenous shocks in 1995, the CBE chose to hold the exchange rate stable in order to preserve the downward trend in inflation. To this end, it drastically contracted money base via stepping up open market operations in early 1995 , thereby pushing up CBE's interest rates to above 50 percent, close to 30 percent in real terms.

Although the CBE succeeded in maintaining stable the exchange rate, and hence, holding inflation under control, the resulting liquidity crunch claimed several victims. A number of financial intermediaries had engaged in pronounced maturity mismatches, most notably Banco Continental (6.4 percent of onshore bank deposits), which, as a result of the sudden and significant increase in CBE's interest rate, fell into deep liquidity problems and ultimately failed in 1996. The CBE managed to isolate the crisis from the rest of the system by assisting banks with ample liquidity support, and in the particular case of Banco Continental by providing it a subordinated loan to restore its solvency and eventually by taking it over. Nonetheless, CBE's interest rate did not come back down to 1994 levels irrespective that inflation continued its slight downward trend throughout 1995.

Under a more auspicious external environment Ecuadoran governments muddled through the post-crisis, keeping the economy and the financial system in an unstable equilibrium in 1996 and 1997. With liquidity conditions restored at a systemic level, interest rates trend-down again, but poor quality of bank assets and the resulting equity shortage might have not been remedied. Therefore, the banking system remained fragile and vulnerable to the effects of adverse external shocks in an environment of institutional weaknesses that would not allow the government to cope effectively with major bank problems.

\section{A Stylized View Of The Financial Crisis}

A string of exogenous shocks occurred, again with renewed virulence, in 1998 while the Ecuadoran economy had not fully recovered from the mid-1990s crisis, thereby unveiling long-standing macroeconomic vulnerabilities and financial system flaws. Whereas the Asian financial crisis had limited effects on the Ecuadoran economy, El Niño floods in the late 1997 and early 1998 destroyed vast agriculture areas, reducing exports and impairing assets of several banks mainly from the Coastal region of the country. By mid-1998, other external shocks hit Ecuador such as the Russian financial crisis and the subsequent Brazilian crisis, which spilled over into the rest of Latin America, including Ecuador. In addition, oil prices in the world market sank to less than $\$ 10$ per barrel-for the Ecuadoran crude-hurting not only the public finances but also making foreign currency even scarcer. As a result of all 
these shocks, market sentiments deteriorated, raising concerns about the macroeconomic outlook and debilitating further the financial system in the process.

\section{A. Outbreak of the Banking Crisis}

While impaired assets were at the heart of the new banking problems, deposit withdrawals were the visible event. The traumatic closure of a small bank (Solbanco) in April 1998 was the spark for Ecuador's banking crisis. It triggered contagion and deposit runs on other banks, including two of the three largest banks, prompting several institutions to seek liquidity support from the CBE to tackle an increasing liquidity crunch, which in turn induced a systemic gradual credit reduction (Figure 13). Contagion was due to the losses incurred by depositors in the closed bank, in particular medium and large depositors who could not recover their savings.

The crisis gained momentum in August 1998 when a medium-size bank was closed after having been unable to honor its obligations and subsequently when the largest bank of the system requested assistance to the CBE. When Banco de Prestamos was closed, ${ }^{21}$ only small savers received payouts from the existing limited deposit guarantee. However, payments materialized after several weeks, in most cases with a "haircut" resulting from the ongoing depreciation of the sucre. In turn, larger creditors did not recover their money even after several years. Financial and macroeconomic problems worsened when Filanbanco, with the largest assets base, the largest stock of credit lines, and the second-largest deposit holdings (14 percent of the onshore system), requested CBE's liquidity support in September sky rocketing its assistance to the financial system (Figure 14).

In absence of effective bank resolution instruments, the first line of defense to cope with liquidity needs was the provision of LOLR assistance. Total emergency loans reached close to 30 percent of money base- - to assist 11 financial institutions-by end-September 1998. In anticipation of potential exchange rate instability, the CBE also adopted a discrete upward shift and widen the crawling band to make room for more exchange rate flexibility. In turn, the government brought in adjustment measures mainly by hiking domestic gasoline prices.

At this stage of the crisis, deposit instability featured "flight to quality" with currency preferences shifting from sucres to dollars. With CBE's currency issue growing by 30 percent during the last quarter of 1998 due, in a great extent, to the continued support to illiquid banks (Figure 15), sucre deposits in the banking system rose 10 percent, whereas foreign currency deposits-measured in sucres-increased 25 percent in the same period. ${ }^{22}$

\footnotetext{
${ }^{21}$ While the central bank granted emergency support to this bank, providing additional assistance was not possible because it had to be legally approved by the CBE Board, which had not yet been nominated by the recently elected government at that time.

${ }^{22}$ Measured in foreign currency, dollar deposits rose 12 percent.
} 
Figure 13. Banks' Liquidity and Credit Crunch

(Reserve requirements and bank loans)

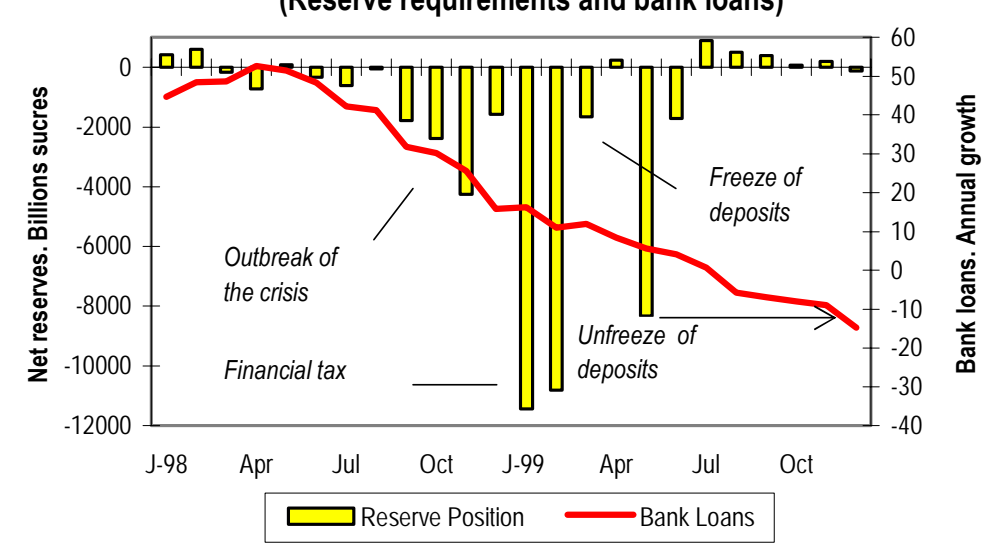

Source: Central Bank of Ecuador

Figure 15. Total Deposits and Currency Issue (Billions of sucres)

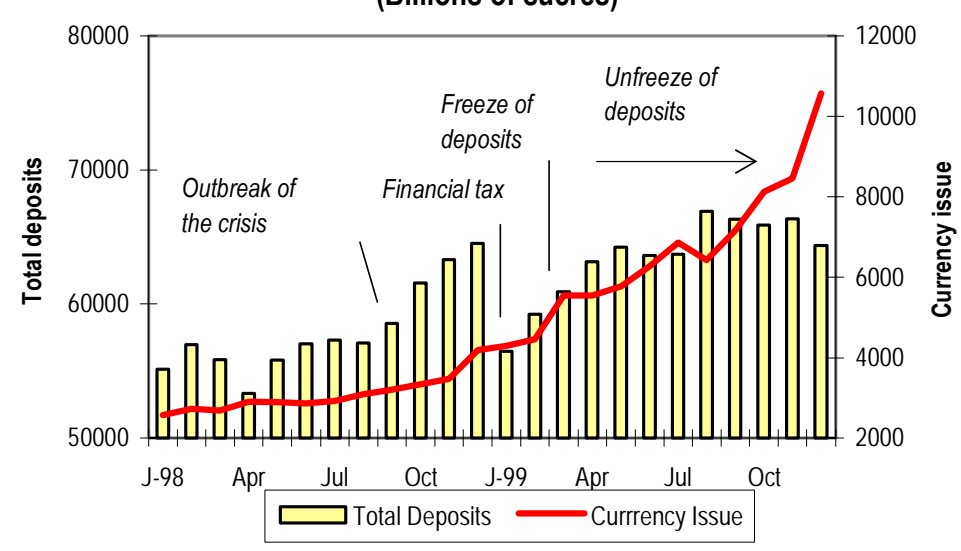

Source: Central Bank of Ecuador
Figure 14. Financial Assistance to Banks (Billions of sucres)

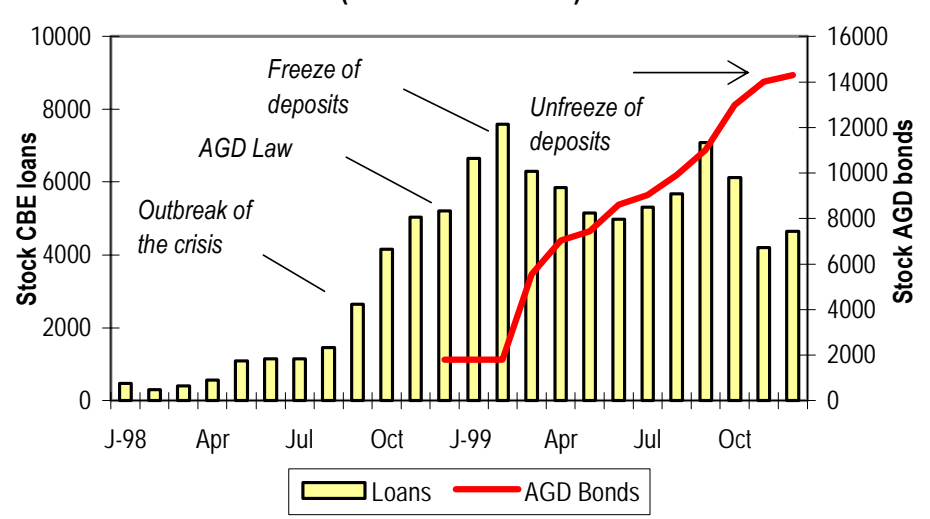

Source: Central Bank of Ecuador

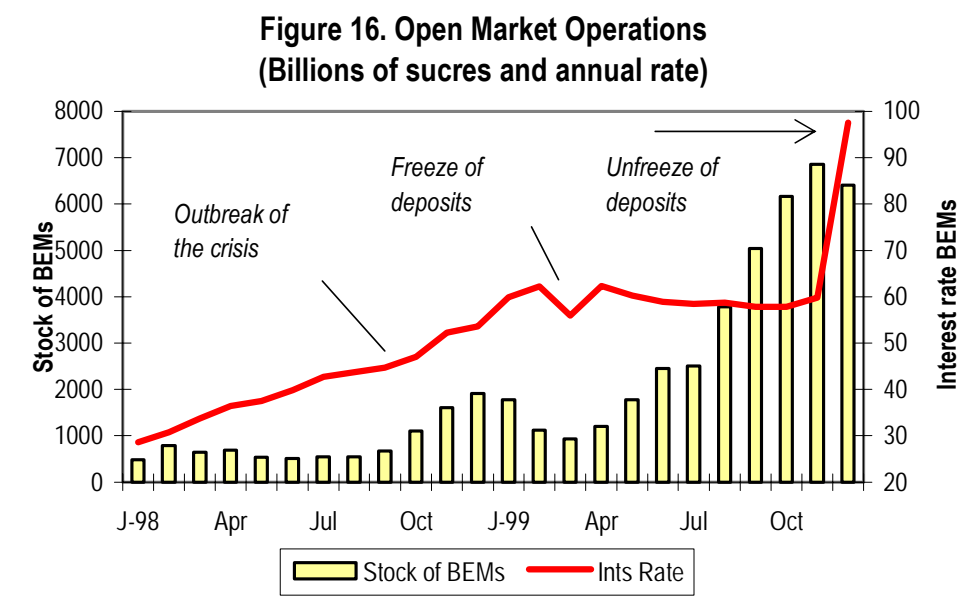

Source: Central Bank of Ecuador 
To cope with soaring monetization, the CBE stepped up open market operations (OMOs) to mop up liquidity, but this did not preclude the market from creating pressures on the domestic currency and the international reserves. While the volume of CBE's short-term paper (Bonos de Estabilización Monetaria, BEMs) tripled during September through November 1998, pushing up CBE's short-term paper interest rates as well (Figure 16), it proved insufficient to fully sterilize the expanded monetization. As a result, the sucre underwent a nominal depreciation of about 24 percent while CBE's net international reserves shrank 7.6 percent over that interval. The US\$300 million slash of banks' foreign credit lines (17 percent of total and close to 20 percent of CBE's international reserves) during the last quarter of 1998 - in the wake of the Russian and Brazilian financial turmoil—was instrumental for explaining the external financial deterioration. In this environment of financial instability, cumulative inflation reached 15 percent and real GDP grew only 0.1 percent in the last quarter of 1998.

\section{B. "AGD Law" and Conflicting Effects of the Blanket Deposit Guarantee and the Financial Transaction Tax}

In light of the limitations imposed by the absence of a suitable legislation to handle banking crises, the government sent to Congress the so-called "AGD Law," which established a blanket guarantee through the Guarantee of Deposits Agency (Agencia de Garantía de Depósitos, AGD), in an effort to restore stability in bank liabilities. ${ }^{23}$ The AGD was also legally entitled to conduct bank resolution, mainly "purchase and assumption operations" (P\&A). ${ }^{24}$ The government also included in the draft law the creation of a 1 percent tax on financial transactions - debits and credits - to substitute the income tax, with the aim of shoring up weak public finances. The "AGD law" was approved in early December 1998.

Exacting a 1 percent tax on all financial transactions from January 1999 onwards was devastating for the financial system as it was imposed in the middle of a liquidity crunch, thereby accelerating the collapse of various financial institutions, including Banco del Progreso, the largest bank of the system measured by deposits. The drain on bank deposits escalated as economic agents did their best to circumvent the tax by transacting outside the banking system. The financial tax was also indirectly a source of additional pressures on the exchange rate, since storing money in foreign currency outside the financial system was easier and, in particular, more secure, given that the largest bill denomination in domestic

\footnotetext{
${ }^{23}$ Such a last resort decision has also been adopted from 1990 onward by Finland, Honduras, Indonesia, Jamaica, Japan, Korea, Kuwait, Malaysia, Mexico, Sweden, Thailand, and Turkey, in the wake of systemic financial crises (see Garcia, 2000).

${ }^{24} \mathrm{P} \& \mathrm{~A}$ refers to financial transactions where a solvent bank purchases a proportion of the assets of a problem bank and assumes a proportion or all of its liabilities. In the event that purchased assets are worth less than the assumed liabilities, either the government or a bank restructuring institution—if it exists—would provide the resulting difference in the form of liquid assets to match the value of assets and liabilities to be acquired by the purchasing bank.
} 
currency was, at that time, equivalent to less than four U.S. dollars. Under these circumstances, demand deposits in the banking system fell 17 percent in January despite currency issue had continued growing strongly.

Despite having available an improved legislation for banking resolution, the government continued closing banks. Except for Filanbanco, which was taken-over by the AGD under too-big-to-fail considerations, six other impaired banks were closed during December 1998 and January 1999, thus materializing the blanket guarantee. Given the lack of fiscal funds, deposits were ought to be paid by the CBE in exchange for long-term securities (AGD bonds). In practice, the AGD started honoring the blanket guarantee with central bank resources only in April 1999, and hence, deposit withdrawals from other banks did not abate in an environment of growing unrest. Lagged payments impinged losses on depositors of closed banks as a result of the accelerating inflation and the persistent depreciation of the sucre, thereby stimulating contagion and eroding market's credibility in the blanket guarantee.

\section{Currency Crisis and Bank Deposits' Freeze}

By early 1999, the speculative run on the sucre intensified and the CBE's international reserves continued to shrink due to the mutually reinforcing effects of the adverse external environment, the withdrawal of deposits associated with the financial tax, and the persistent monetization of the banking crisis. World oil prices were still falling and the Brazilian crisis had come to a head, leading to capital outflows from most other countries in the region. Internally, in addition to the perverse effects of the 1 percent financial tax, monetization of the banking crisis continued, including the provision of open-bank assistance to Filanbanco. As a result, money base expanded 18 percent during the first quarter despite sterilization and the 30 percent decline in CBE's net international reserves.

As the demand for dollars gained momentum and with a reduced amount of international reserves, the $\mathrm{CBE}$ could not defend the exchange rate band anymore and shifted to a clean float in February. The new exchange rate regime left the economy without an anchor to hold down inflationary expectations, while an exchange rate overshooting took place as the market reacted to the CBE's inability to stop printing money, and hence, to containing the sucre depreciation. On the other hand, once the CBE stopped intervening in the interbank foreign exchange market foreign currency reserves stabilized (Figure 17). The rapid depreciation of the sucre - nearly 50 percent in January and February 1999-hit hard banks' unhedged foreign currency debtors, thereby eroding banks' equity, and hence, further impairing their solvency. 
Figure 17. Net International Reserves and Nominal Exchange Rate (Millions US dollars and sucres per dollar)

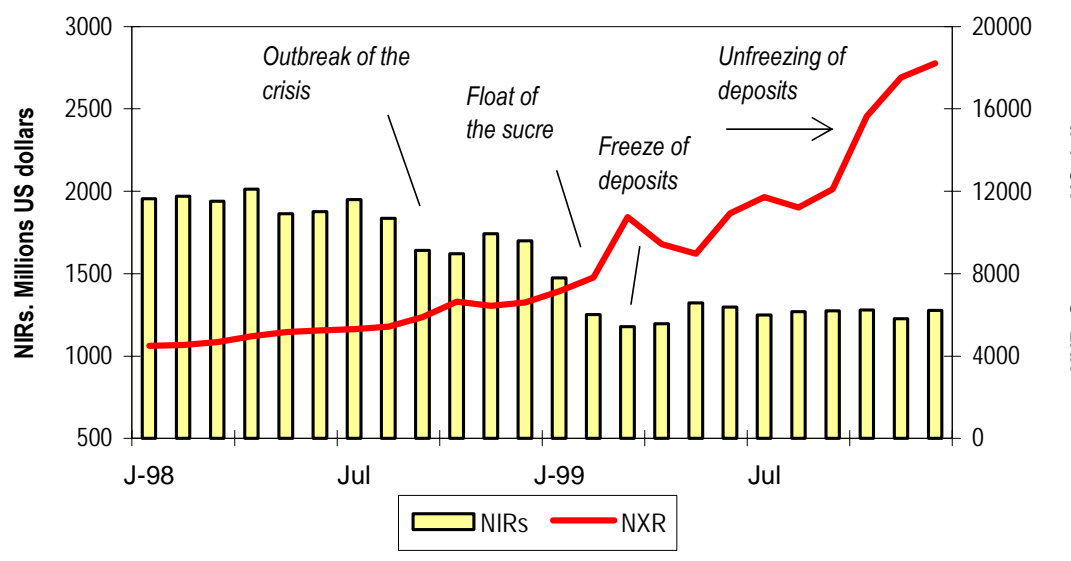

Source: Central Bank of Ecuador

Figure 18. Preference for Cash over Demand Deposits

(Billions of sucres and ratios)

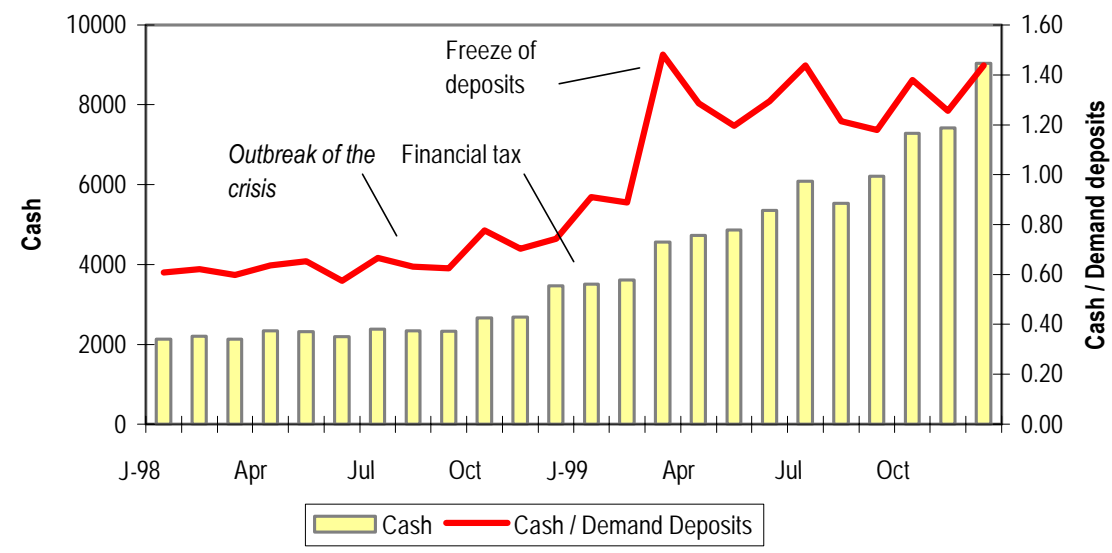

Source: Central Bank of Ecuador

Figure 19. Inflation and Money-Base Growth

(Annual percentage rate)

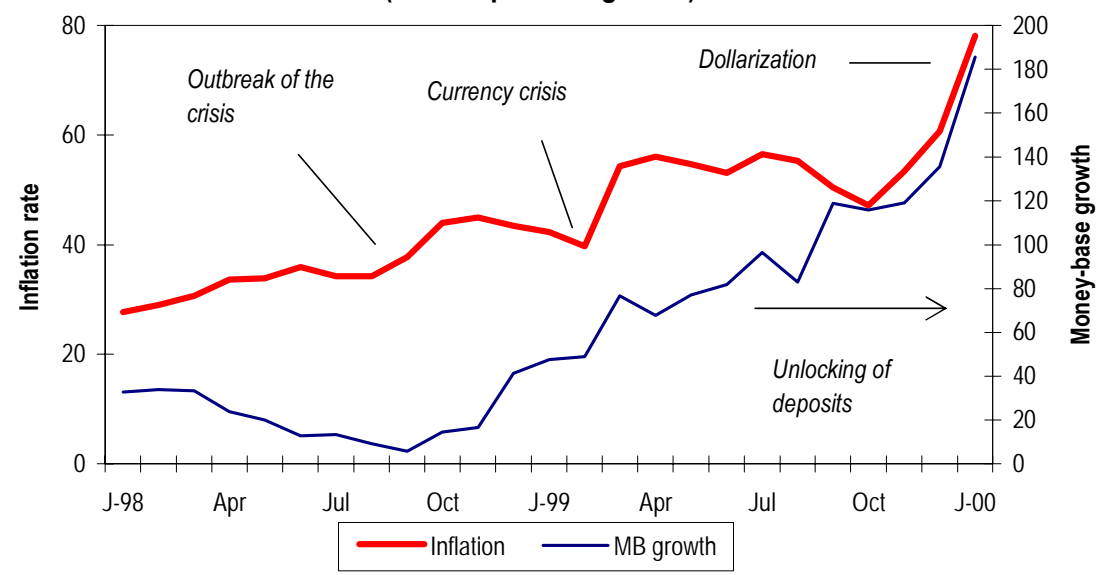

Source: Central Bank of Ecuador 
In the midst of a currency crisis, and with Banco del Progreso demanding liquidity to the CBE, the government declared a bank holiday in March 1999. Then, in an environment of systemic lack of confidence, the government imposed a widespread freeze of bank deposits at the end of a one-week bank holiday. Time deposits and repurchase agreements were locked for at least one year and saving deposits in excess of US\$500 and one half of checking account balances were frozen for six months. ${ }^{25}$ In exchange, depositors received negotiable claims on their respective banks (Certificates of Reprogrammed Deposits, CDRs) with a discount that varied according to the market's perception about the financial strength of each bank. ${ }^{26}$ As a result of the bank holiday and the freeze of deposits, the lack of confidence in the banking system escalated and the preference for cash versus demand deposits jumped from a ratio of less than 0.90 to nearly 1.5 between February and March 1999, which could be interpreted as a precautionary decision in anticipation to new confiscatory measures from the government (Figure 18).

Despite the deposit freeze, several institutions-Banco del Progreso among them-were shut down as deposit runs continued unabated in a number of banks, further materializing the blanket guarantee. ${ }^{27}$ By adopting a widespread freeze of deposits, the government implicitly recognized the blanket guarantee's inability to stabilize liabilities in the financial system only three months after having announced this safety net. Freezing deposits temporarily halted the fall of the sucre and stabilized inflation, but at the expense of impairing the functioning of the payments system, which was then instrumental for the more than 7 percent of GDP drop in 1999. In practice, by imposing a freeze of deposits, the government "bought time" to clean up the banking system. To this end, it contracted international audit firms to assess banks' soundness as part of a program negotiation with the IMF. In the mean time, the public's perception of the deposit freeze as a confiscation of savings and wealth made it less trusting of the country's laws and institutions.

\section{Unfreezing of Deposits and the Banking and Monetary Collapse}

The hiring of international auditors to assess the soundness of the banking system was an open recognition of Ecuador's institutional weaknesses, in particular, of the SBS's inability to ascertain the soundness of the financial system. The findings of the auditors' evaluationsbased on the consolidation of banks' onshore and offshore information-showed great

\footnotetext{
${ }^{25}$ Ecuador's deposit freeze was more aggressive than others adopted in the region, such as Argentina's Bonex Plan and the Collor Plan in Brazil (see Cardoso and Rigobon, 1999), the recent Uruguayan reprogramming of deposits in 2002, and the composite "corralito" and "corralón" in Argentina 2002.

${ }^{26}$ CDRs were issued at depositors' request and were usable to buy durable consumer goods and real estate.

${ }^{27}$ Strictly speaking, Banco del Progreso's main shareholder decided unilaterally to close the bank claiming that his bank had received insufficient financial assistance from the CBE. Unexpectedly, rather than liquidating the bank, as it was required by the LFSI, the government authorized the banker to continue working within the bank while it was closed and provided him 90 days to capitalize. Eventually, the bank's main shareholder never injected capital and hence the AGD took control of the closed bank.
} 
divergences with respect to previous reports produced by the SBS, and led to the closure of another 4 banks amid government announcements of a final purge of the banking system. ${ }^{28}$

The gradual unlocking of deposits from mid-1999 onward proved to be premature, and hence, it triggered a new wave of deposit withdrawals. In an atmosphere of increasing social unrest and in an effort to normalize the functioning of the payments system, the government started to gradually unlock deposits without assurances of appropriate liquidity safeguards in the banking system. Deposit withdrawals then picked up once again as a result of the lack of clear signals about economic stabilization and amidst recurrent rumors of new bank holidays. Moreover, renewed deposit withdrawals translated into an enhanced demand for dollars intensifying the depreciation of the sucre. As CBE's payment-on behalf of the government — of the blanket guarantee gradually increased and liquidity assistance continued CBE's involvement in the banking crisis reached a peak in September 1999 when total monetization associated to the banking crisis mounted to 12 percent of GDP. ${ }^{29}$

In the mean time, as government liabilities persistently increased and due to the reduced level of CBE's international reserves, in September 1999 the Ecuadoran government suspended payments on its external commercial and Paris Club debt. The failure to honor external debt obligations impacted not only foreign creditors but also domestic banks holding government securities, further eroding the value of their assets, and hence, their solvency.

Government's debt default deteriorated even more market sentiments thereby accelerating deposit withdrawals. Despite previous official announcements claiming a turnaround of the banking crisis, two additional large banks failed in October 1999, which led the AGD and the $\mathrm{CBE}$ to take control of them to avoid further bank closures and additional monetization. ${ }^{30} \mathrm{At}$ the same time, as the use of CBE resources persisted to honor guaranteed deposits, base money growth skyrocketed at annual nominal rates of over 100 percent - real rates above 50 percent - toward the end of 1999. The CBE was then unable to mop up liquidity-the stock of BEMs tripled during the second half of 1999_-given that the demand for sucres plummeted in parallel with a continuous dollarization of bank liabilities. As a result, a second currency crisis took place and inflation accelerated its pace prompting the government to officially dollarize the economy (Figure 19).

\footnotetext{
${ }^{28}$ The negative 234 percent risk-weighted-capital-asset ratio as of March 1999 calculated by the international audits for Banco del Progreso illustrates such divergences since the SBS had not found insolvent this bank beforehand.

${ }^{29}$ This amount is comparable to the liquidity support provided in Malaysia, 13 percent of GDP, and is smaller than the assistance provided in Indonesia and Thailand, 16 and 22 percent of GDP, respectively during the Asian crisis (see Hoelscher and Quintyn, 2003).

${ }^{30}$ Banco Previsora was taken-over by the AGD-owned Filabanco while Banco del Pacífico was merged with the CBE-owned Banco Continental.
} 
While preconditions for dollarization-mainly strong public finances and a sound and stable financial system - were not in place, the full dollarization of the economy succeeded in stabilizing the financial system and to stop the collapse the economy. It is fair to say, though, that stabilization was also achieved thanks to a complete political reshuffle-including the President of the Republic - that brought in a favorable shock to expectations as it signaled a turn around in the running of the country. In addition, a favorable external environment, including a high international oil price and renewed IMF and other multilateral support, underpinned domestic economic management, thereby helping to restore confidence in Ecuador's economic outlook at the beginning of dollarization. ${ }^{31}$

\section{Exacerbating Effects of Institutional Weaknesses, Fiscal Rigidities, AND FinanCIAL DOLLARIZATION}

Despite the tremendous growth of the literature on banking crises in recent years, few of the analyses have touched more than marginally on the role of institutional factors in affecting banking crises and their aftermath. ${ }^{32}$ In countries where institutional weaknesses are germane the narrow macro-financial approach offers a limited understanding of the causes, dynamics, and effects of the crises. Institutional arrangements at the time of a financial crisis are relevant because they lay the ground for government and central bank's policy response and influence the nature and timing of decisions aimed at confronting the crisis. Countries that enjoy strong institutions - including appropriate legal arrangements and the rule of law-are better prepared to contain financial crises at an early stage. In turn, countries featuring institutional flaws have smaller chances of successfully confronting financial crises, and ultimately bear the high cost of a systemic crisis. ${ }^{33}$

\footnotetext{
${ }^{31}$ A final judgment about the lasting benefits of Ecuador's dollarization is beyond the scope of this paper.

${ }^{32}$ Modern economic literature is increasingly highlighting the role of institutions in explaining differences in the quality of governments and their policies, and in the level of income and development between countries (see for example the recent papers by Acemoglu et al., 2002 and Rodrik et al., 2002), but the link between quality of institutions and financial crises events has received no attention in the literature. From a policy perspective, however, there is recognition of the relevance of institutional aspects by the official international community. The Financial System Assessment Program developed by the IMF and the World Bank, which is being executed since 2000, includes an assessment of the countries' observance of Basel Core Principles for effective banking supervision, of transparency practices, and of the legal and institutional framework to prevent the stability of financial systems and to manage banking crises.

${ }^{33}$ The management of Sweden's banking crisis in the early 1990s is a case in point since the rule of law and institutions' strength, underpinned by a broad political consensus to handle the crisis, allowed the Swedish government to contain increasing bank distress that had challenged stability at a systemic level. Like Ecuador, the Swedish government brought in a blanket deposit guarantee and created a bank-restructuring bureau; unlike Ecuador, the Swedish government was able to adopt effective bank resolution decisions to quickly restore markets' confidence in the banking system without imposing a high fiscal cost on the economy (see Ingves and Lind, 1996).
} 
Fiscal adjustment is also a key component of an early policy response to financial crises in countries where public finances are in a weak condition, and in particular when government financing has dried up. The lack of fiscal tightening signals the government's inability to align public finances with a deteriorating macro-financial setting and, hence, it worsens furthermore the adverse sentiment of markets associated to the banking crisis. ${ }^{34}$

In turn, in the event of a systemic crisis, high financial dollarization tends to foster portfolio reallocations toward dollar assets, creating pressures to foreign exchange depreciation and losses of international reserves, all of which may finally be conducive to a currency crash. In addition, financial dollarization reduces government's scope for handling a systemic crisis given that financial safety nets perform a limited role in protecting growing dollar deposits as international reserves become a binding ceiling given central bank's inability to print foreign currency. 35

\section{A. Restrictive Institutional Weaknesses}

Banking problems in Ecuador soon gained momentum and ultimately reached systemic proportions - in a great extent - because of the lack of an appropriate legal and institutional framework to prevent and manage banking crises. At the beginning of the crisis, the government and the CBE had to invariably follow one of two avenues: either to provide extensive financial assistance by printing money or to close impaired banks paying small depositors and liquidating its assets — in practice after a significant lag — to pay the remaining liabilities (see Appendix I). While the first alternative was conducive to macroeconomic instability, the traumatic closure of banks would inevitably produce contagion to other financial institutions.

After the closure of the first two banks in 1998 triggered contagion to other institutions, Ecuador had probably no other alternative than to provide ample central bank's emergency assistance to avert further contagion and a systemic problem, with the expectation of establishing soon an appropriate management framework that would allow reducing monetization of the banking crisis. This institutional setting was envisaged to follow from the approval of the "AGD Law," which would include a blanket guarantee, which was seemingly a desperate decision to contain mounting bank deposit withdrawals.

\footnotetext{
34 The role of fiscal policy during financial crises has been intensively debated over the last few years, in particular following the Asian crisis. In a Keynesian setting, the discussion has basically focused on whether the government should play a pro-cyclical or a counter-cyclical role during financial crises given that the fiscal stance contributes to deepen or mitigate the crisis' contractionary effects via its impact on aggregate demand. However, this debate is relevant under circumstances where fiscal imbalances and a high debt burden are not a source of macroeconomic vulnerability or when fiscal weakness is not the root of the crisis. In such scenario, not tightening fiscal policy makes economic contraction stemming from financial crises less severe, which in the end reduces the associated negative effects on bank assets.

${ }^{35}$ See Ingves and Moretti (2003) for a discussion on this matter.
} 
The "AGD Law" was enacted after protracted political negotiations. The delay responded to various financial and fiscal issues addressed in the law, which involved the distribution of potential gains and losses associated to the new legislation. As a result, Ecuador could only count on an improved institutional setting to manage the crisis only six months after the first bank was closed, when the accumulated liquidity support from the CBE had reached nearly 90 percent of money base or 3.6 percent of GDP by of end-November 1998, and hence, when the exchange rate and the central bank international reserves were already under intensive pressure. $^{36}$

The "AGD Law" created instruments to expeditiously resolve market exiting of failing banks, mainly P\&A, and entrusted the government with powers to capitalize and manage impaired but viable banks. In pursuing these objectives the "AGD Law" created a new institution, the Deposit Guarantee Agency (AGD), with powers to pay guaranteed liabilities as necessary and to resolve the situation of failing banks. The government's full guarantee covered bank deposits and external credit lines at the expense of a large fiscal contingency and the creation of moral hazard distortions.

In addition, since the legal reform was adopted in the middle of systemic crisis, the "AGD Law" underpinned the central bank's involvement in banking crisis. The "AGD Law" authorized the CBE to engage in open-bank assistance to systemically important institutions, which however would require a massive print of money, thereby contributing to monetary instability. In practice, previous unbounded LOLR assistance was surrogated with legal provisions to provide ample liquidity and solvency support to banks administrated by the AGD and to finance bank restructuring and to cover government's deposit guarantee. In this perspective, it was critical that the Ecuadoran authorities would stop traumatic closure of banks and alternatively favor the timely use of the newly created P\&A mechanisms, to prevent the materialization of the fiscal contingency associated to the payment of the blanket guarantee, and hence, the broad monetization of the crisis and eventually the economic meltdown.

While the "AGD Law" provided more efficient and cost effective instruments of bank resolution, they were not exercised and rather the government continued closing banks without restoring confidence in bank depositors. The new legislation allowed the government to get rid of previous corner solutions - broad monetization or traumatic closure of banks - to handling banking problems, which appeared conducive to macroeconomic instability and eventually to a full-blown financial crisis as well. However, the approach selected by the government materialized the blanket guarantee, which worsened the outlook of public finances and perpetuated the monetization of the banking crisis leading to further

\footnotetext{
${ }^{36}$ In this regard, Ecuador shows some similarities with the Indonesian crisis, where governance problems intensified the 1997 financial crisis and delayed its resolution (see Enoch and others, 2001).
} 
macroeconomic instability. ${ }^{37}$ Moreover, since the payment of the guarantee of deposits was not expeditiously executed, deposit runs were not arrested.

How to explain the paradox of a government choosing a costly approach to cope with a financial crisis, which in addition did not restore confidence in banking system deposits? There are at least two possible answers, namely the institutional weakness of the newly created AGD and, probably more important, the political economy restrictions imposed by Ecuador's fragmentation (see Box 1 in Appendix I). While the first explanation can explain the seemingly sluggish initial reaction of the AGD, the second one is relevant to understand the dynamics of the crisis management in 1999.

The AGD was required to have a strong expertise to conduct, for example P\&A, such that weak banks would be partially or fully absorbed by solvent institutions, thereby minimizing disruption in depositors' confidence and fiscal costs. However, the recently created AGD completely lacked this expertise, and hence, it could not handle the failure of six banks, which materialized during the first two months that followed the creation of the AGD. ${ }^{38}$

Probably more important seems to be political economy considerations as they restricted the government's degrees of freedom to apply a least-cost bank resolution strategy. In practice, P\&A would have implied transferring assets and liabilities from mostly Guayaquil-based failing banks to mostly Quito-based viable banks, and hence, to transfer wealth and power from one rival region to the other, which would have demanded strong institutions and governance. Therefore, no P\&A were applied except for Banco Popular, the only Quitobased failing bank following the enactment of the "AGD Law," which was partially absorbed by another Quito-based bank. In absence of appropriate institutional and political economy conditions conducive for the implementation of $\mathrm{P} \& \mathrm{~A}$, powerful economic groups had a decisive influence in government's policies and decisions, which eventually led to a high cost of the crisis and to a broad and unequal distribution of its losses.

Similar political economy constraints made it also difficult the recovery of assets from the closed banks. Since large bank debtors were also powerful economic groups, they managed to avoid the payment of their debts, and hence, by end-2003, the AGD have had limited success in collecting loans from the closed banks. By the same token, vested private interests took advantage from the management of the crisis and made large and instantaneous profits. This explains how the government authorized CDRs transactions at the cost of impairing the solvency of government-owned financial institutions-such as the National Finance

\footnotetext{
${ }^{37}$ The modality of honoring the blanket guarantee followed the mandate of the State Lawyer who required cash payments - printing money given fiscal constraints - rather than delivering the deposit guarantee with government bonds.

${ }^{38}$ Implementing P\&A typically require conducting technical procedures to assure that the orderly transfer and payoff of deposits is executed smoothly, on time, and transparently (see He and Seelig, 2000).
} 
Corporation, a second-tier bank, and the previously taken-over commercial bank, Filanbanco. ${ }^{39}$

The failure to implement new bank resolution instruments was conducive to the adoption of the costly bank holiday and freeze of deposits, which boosted the cost of the crisis. The bank holiday induced adverse selection, and hence a systemic lack of confidence, as it conveyed the message to the market that all banks were impaired. In turn, the freeze of deposits produced a long-term confidence damage since depositors realized that financial contracts had been unilaterally broken. The government's alternative would have been to authorize the opening exclusively of viable banks at the end of the bank holiday and to maintain closed those unviable institutions, as Uruguay did in 2002, Argentina during the mid-1990s, and the United States during the 1930 s. $^{40}$ This alternative decision would have contributed to restore bank deposits' stability, would have tempered adverse selection induced by the bank holiday, and in general, would have mitigated the enduring and broad loss of confidence in the financial system.

\section{B. Impact of Fiscal Policy Rigidities and Financial Transaction Tax}

Given that public finances were already in a weak condition and due to the persistent decline in oil prices at the time of the banking crisis, Ecuador had no other alternative but to tighten fiscal policy to mitigate the increasing market concerns about a deteriorating macroeconomic outlook. However, as discussed in section II, Ecuador approached the late 1990s with small room for maneuvering to adjust the stance of fiscal policy to exogenous shocks, without having access to capital markets, and featuring an "adjustment fatigue" after almost two decades of incomplete and discontinued efforts of macroeconomic stabilization. Thus, public finance restrictions turned out to be a significant limitation for the management of the banking crisis.

In 1999, except for the tax on financial transactions, the government repeatedly reversed fiscal adjustment decisions constrained by pressures from organized political groups and social organizations opposed to the government. Previously, fiscal tightening was possible in September 1998, although it proved to be insufficient to compensate the revenue shortages associated to the crumble of the external oil price and a public sector wage bill increase of nearly two percentage points, which together boosted the fiscal deficit to close to 6 percent of

\footnotetext{
39 Typically, under these transactions, AGD bonds were sold to state-owned institutions at face value after having been acquired by particulars with a big discount in the secondary market.

${ }^{40}$ In Uruguay, only the viable banks were opened at the end of the bank holiday in mid-2002, and hence, only a reduced reprogramming of bank deposits was necessary. As a result, the damaging effect to the payments system was mitigated, adverse selection was avoided, and further contagion was contained. Moreover, the Uruguayan government's discrimination between viable and unviable banks contributed to gradually restoring confidence in the banking system, and hence, marked the beginning of the turn around of the banking crisis as opposed to what happened in Ecuador, where the bank meltdown continued after the bank holiday. In the other two countries, no reprogramming of deposits was necessary.
} 
GDP. The public sector had then to close its financing gap by raising funds in the domestic bonds market and by drawing down deposits in the CBE, which in November reached 5 percent of money base. The gradual recovery of the oil price partially mitigated the lack of fiscal adjustment in 1999, driving the fiscal deficit to less than 5 percent of GDP. In any case, Ecuador featured a worsening fiscal position while the banking crisis unfolded, which contributed to deteriorate market sentiments, and thus, to aggravate the financial crisis.

Restrictions to access capital markets also limited the government's ability to finance the fiscal deficit during the initial deposit runs and later when the full-fledged financial crisis materialized. ${ }^{41}$ The government's inability to raise funds in international markets was associated with the country's high debt burden, which by mid-1998 had reached nearly 100 percent of GDP. It was also due to the weakness of public finances, and to a reputation problem stemming from the 1987 unilateral commercial debt default. As a result, voluntary external financing completely dried in 1999. Notwithstanding the enhanced exposure to a potential government debt default, local financial institutions continued demanding dollar government securities during 1998 and the first part of 1999 because of its high return compared to other foreign assets, and because government paper could be used as collateral to access to the CBE's automatic liquidity window. However, as uncertainty about the sustainability of public debt increased, in line with the unfolding of the financial crisis, this source of financing dried up as well. Due to the steep depreciation of the sucre, total public debt to GDP ratio sky rocketed, reaching more than 130 percent by end-1999 (Figure 20).

It is this mixture of fiscal rigidities and political economy constraints that led the government to the mistake of imposing a 1 percent tax on financial transactions in the middle of a banking crisis. ${ }^{42}$ While the new tax boosted fiscal revenues, more than compensating the simultaneous elimination of the income tax, it depressed the demand for money by heightening public's preference for cash, and hence, it led to further deposit withdrawals and to the closure of several small and medium size banks. Thus, the new tax neutralized the effect that was sought with the announcement of the blanket guarantee as it encouraged depositors to pull their money out of banks. In turn, the closure of banks activated the fiscal contingency associated to the blanket guarantee, and hence, worsened the fiscal outlook.

Public finance rigidities and institutional and political economy restrictions to tighten fiscal policy made it also difficult to achieve a timely agreement on an economic program with the IMF, which could have contributed to temper negative expectations about future macro-

\footnotetext{
${ }^{41}$ As a way of comparison, with a strong fiscal position and a low debt to GDP ratio the Dominican Republic was able to raise US $\$ 600$ million (about 3 percent of GDP) in the international capital markets during the early phase of the 2003 banking crisis. Access to capital markets allowed the government to underpin central bank's international reserves, and hence, to mitigate the initial pressures on the domestic currency.

${ }^{42}$ Other countries in Latin America (Argentina, Brazil, Colombia, Peru, and Venezuela) had brought in similar taxation over the 1990s, but the tax base was typically narrower and the rate smaller (see Kirilenko and Perry, 2003).
} 
financial developments. ${ }^{43}$ As Ecuador was unable to deliver an economic program based on a sustainable improved fiscal position and a coherent management of the banking crisis, negotiations with the IMF prolonged over 1999 without agreement. ${ }^{44}$ As a result, the country could not obtain the badly needed external financial support to weather the financial turmoil, further deteriorating market sentiments and contributing to accelerate the financial meltdown. Ecuador only worked out an arrangement with the IMF in March 2000 after protracted and difficult negotiations, when the economy had already collapsed. ${ }^{45}$

A clear manifestation of the growing negative expectations about Ecuador's economic outlook was the sharp increase in the country risk and the persistent curtailment of foreign credit lines to commercial banks (Figure 21). These external developments exacerbated foreign currency demand and hastened the currency crisis. In addition, the September 1999 debt default undermined even more markets' confidence and further impaired the financial position of some local banks that owned Brady debt and other commercial debt paper. As a result, market jitters reappeared fueling a new wave of deposit withdrawals.

\section{Role of Financial Dollarization}

Crisis events in Ecuador provide empirical evidence about the potential role of financial dollarization in accelerating a currency crash during a banking crisis and the limitations that financial dollarization imposes to handle a systemic crisis. However, it should be noted that the final outcome of the Ecuadoran crisis was not independent from the restrictions produced by the country's institutional weaknesses and the fiscal rigidities referred to above. ${ }^{46}$

As the banking crisis unfolded in an environment of adverse external conditions, CBE's partial sterilization failed to preserve monetary stability. CBE's emergency assistance reached 120 and 135 percent of the monetary base by December 1998 and February 1999, respectively. This monetization was sterilized only partially to avoid the impact of a sharp increase in interest rates on illiquid banks. In addition, given that the CBE was legally precluded from providing LOLR assistance directly in dollars, the CBE intervened actively in the interbank market selling dollars to match foreign currency demands.

\footnotetext{
${ }^{43}$ Mexico during the mid-1990s, the Asian countries in 1997 and 1998, Colombia in 1999, and more recently Uruguay (2002), and the Dominican Republic (2003), illustrate the benefits of an early IMF support, while Venezuela during the mid-1990s and Argentina in 2002 provide examples in the opposite sense.

${ }^{44}$ The replacement of the income tax with the financial tax was instrumental in slowing down the pace of Ecuador's negotiations with the IMF.

${ }^{45}$ See Fischer (2001) for a brief chronological summary of these cumbersome negotiations.

${ }^{46}$ In this regard, the Ecuadoran crisis episode does not oppose necessarily the conclusions from Arteta (2003), who finds no empirical evidence that financial crises are more costly in highly dollarized economies and that macroeconomic and exchange rate policies are more important.
} 
Figure 20: External and Internal Public Debt (Percent of GDP)

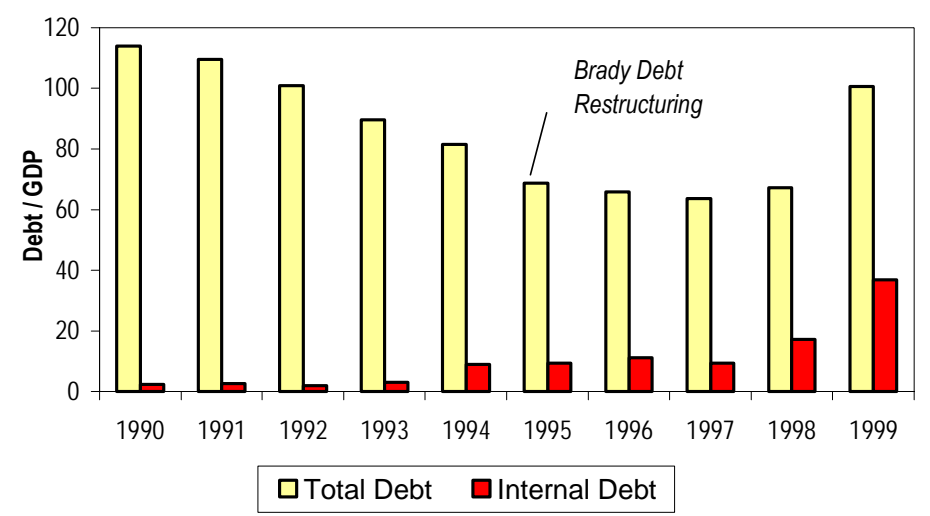

Source: Central Bank of Ecuador

Figure 22. Banks' Dollar Deposits and Interest Rates (Onshore banks. Dollar rates \& sucre-equivalent rates)

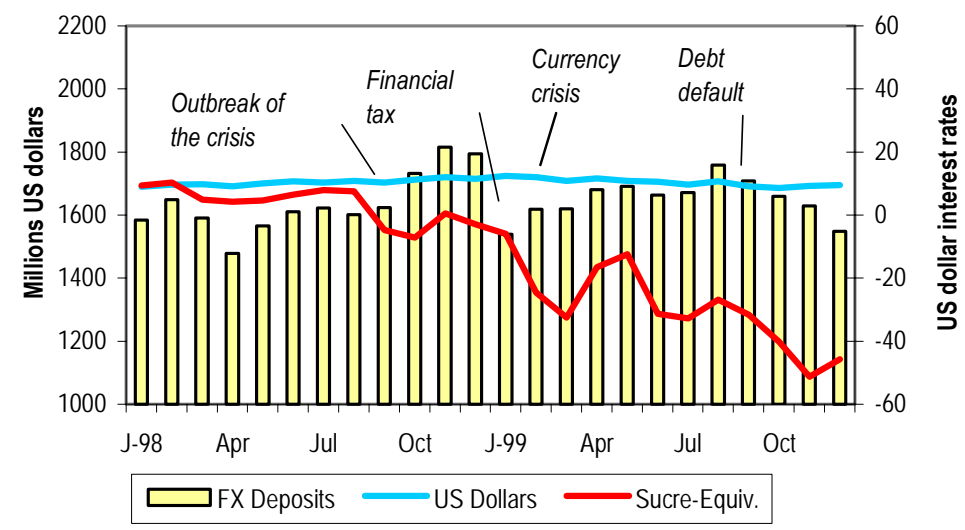

Source: Central Bank of Ecuador
Figure 21. External Credit Lines and Country Risk (Million of US dollars and index number)

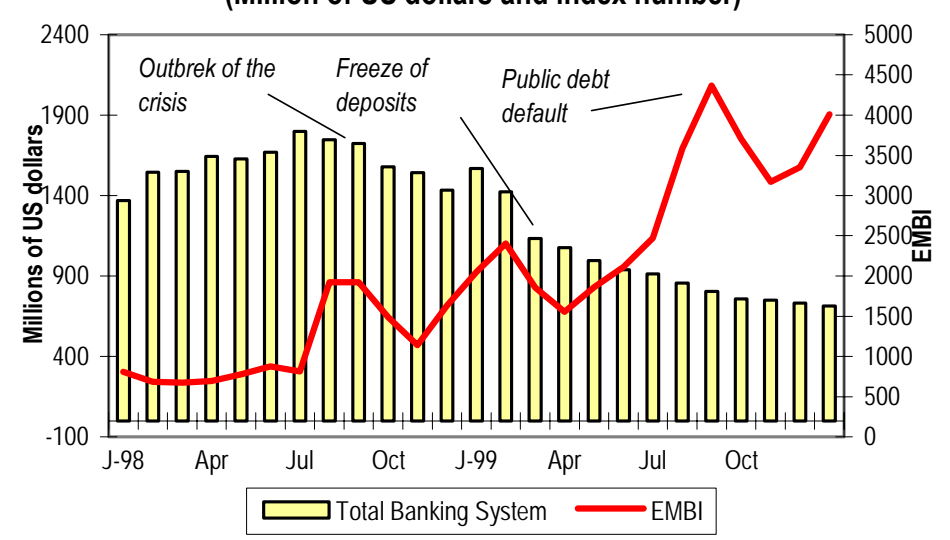

Source: Central Bank of Ecuador

Figure 23. Total Deposits and International Reserves (Onshore banks. Billions of sucres)

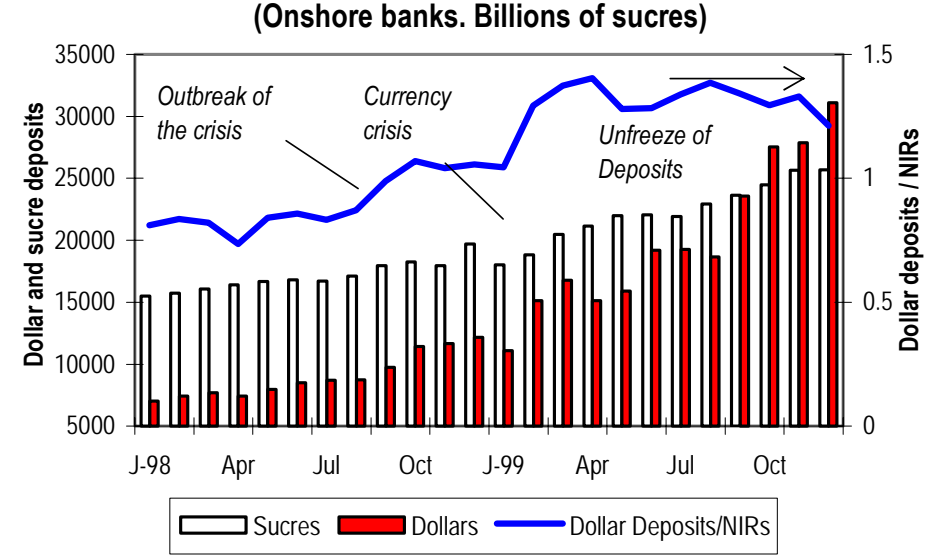

Source: Central Bank of Ecuador 
Excessive monetization spurred deposit dollarization due to return considerations. Deposit dollarization boosted as market participants shifted to dollar denominated assets - although this trend was interrupted by various events such as the inception of the financial transaction tax, the freeze of deposits, and the default of the public sector debt-encouraged by the higher return in dollar deposits as equivalent sucre-deposit rates turned increasingly negative as the crisis unfolded (Figure 22). Dollar demand was also fueled by the supply of a wide variety of financial services and the widespread use of financial contracts denominated in foreign currency, which typically grow in dollarized economies.

Risk considerations also intensified depositors' foreign currency demand since the acceleration of inflation and the drain of CBE's international reserves signaled a potential crumble of the sucre, which would slash the value of sucre deposits. Pressures on the domestic currency were accompanied by a simultaneous drain of CBE's international reserves until February 1999. With dollar reserve requirements already reduced at the minimum by the $\mathrm{CBE}$ - in order to release foreign currency availability to banks - and a seemingly deteriorating condition of banks, depositors had good reasons to doubt about banks' ability - at least of some of them-to honor their deposits and to have concerns about the convertibility of their dollar-deposits.

The excess of dollar deposits vis-à-vis central bank's international reserves raised doubts about CBE's ability to fully exercise its role as LOLR. The excess of foreign currency deposits — not counting the offshore-over CBE's international reserves by late 1998 signaled that the CBE confronted limitations to provide financial assistance to cope with dollar deposit withdrawals (Figure 23). Furthermore, the reduced amount of central bank's international reserves also raised doubts about the likelihood that the government could honor the blanket guarantee. In light of these worrisome indicators, depositors not only shifted to dollar assets but also left the banking system, in particular during the last quarter of 1999 as the unlock of deposits materialized.

Banks also shifted to dollar assets, in particular to highly liquid assets to confront deposit withdrawals and in anticipation to the two currency crisis in 1999. The reallocation of bank portfolios responded to return and risk factors like those embedded in depositors' decisions, but it also reflected a speculative behavior before devaluations during the crawling band period, including those of March and September 1998 (Figure 24). At the same time, banks could not count on ex-ante liquidity of government securities since they gradually lost market value as public finances worsened and the chances of a government debt default increased. ${ }^{47}$ In addition, discounting government securities at the CBE's liquidity window provided only partial and decreasing liquidity vis-à-vis their face value, since the CBE marked to market these securities when used as collateral in repo operations.

\footnotetext{
${ }^{47}$ The Argentinean and Uruguayan financial crises record a similar experience.
} 
Figure 24. Banking System Liquidity (Foreign and domestic currency)

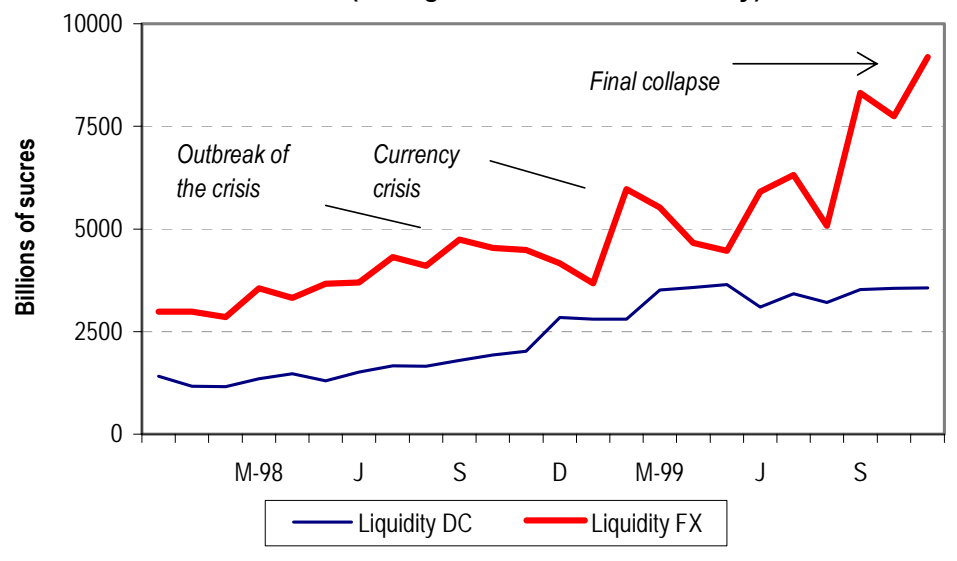

Source: Central Bank of Ecuador

Figure 25. Dollar Loans and Share in Total Loas

(Performing and non-performing loans)

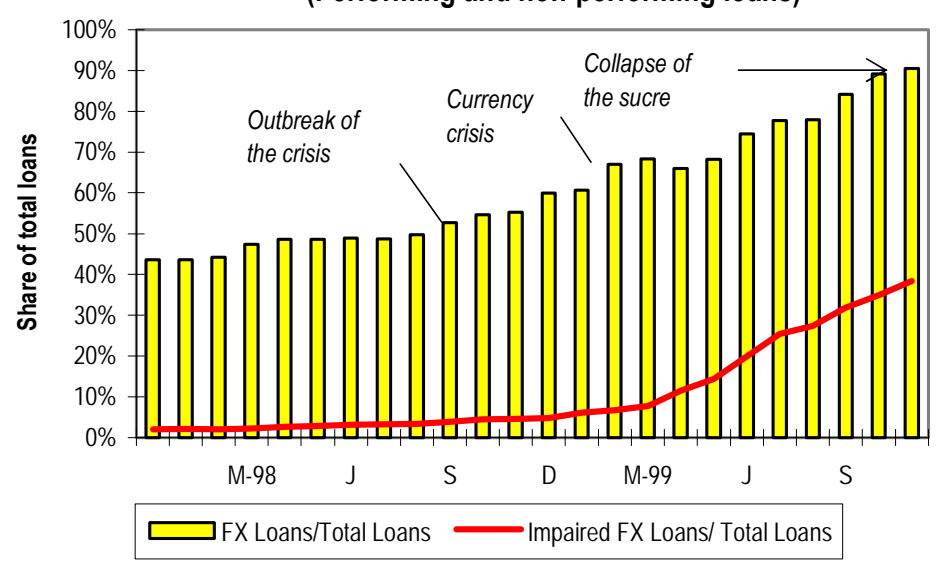

Source: Central Bank of Ecuador

Figure 26. Open-Market Operations and Interest Paid (Net flows and percentage rates)

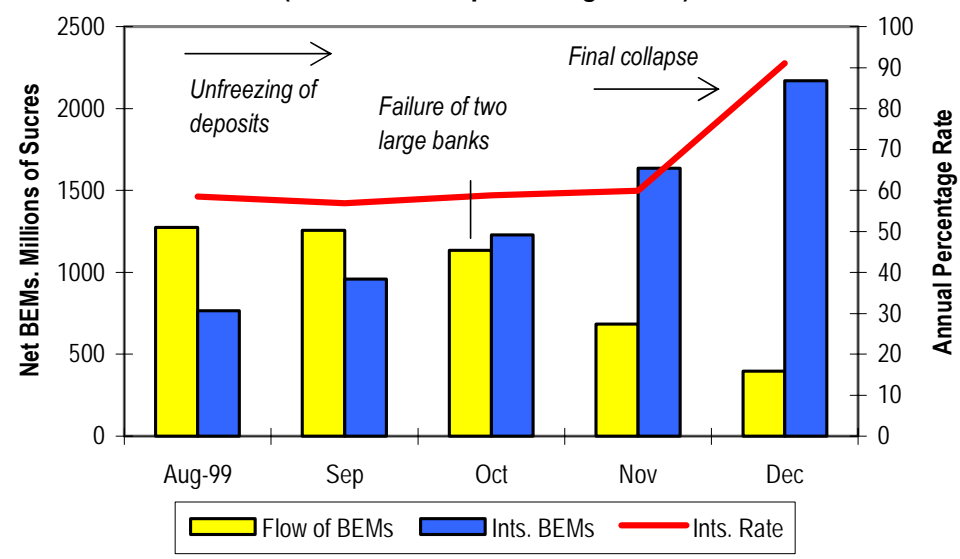

Source: Central Bank of Ecuador 
The swift depreciation of the sucre also hindered unhedged borrowers' balance sheets, limiting their capacity to repay their loans, and hence, indirectly eroding banks equity. While the book value of loans denominated in foreign currency featured approximately 50 percent of total loans at the onset of the Ecuadoran crisis, this ratio rapidly picked up to more than 90 percent towards end-1999 following the domestic currency depreciation. In addition, reported impaired loans - including non-performing loans and foreclosed assets-increased from 4 to nearly 50 percent of total dollar loans, thereby rapidly undermining the value of bank's equity (Figure 25). Thus, financial dollarization and a rapid foreign exchange depreciation compounded to exacerbate- the seemingly previously existing — solvency problems, which added to deep liquidity shortages and laid the ground for a full-fledged banking crisis.

In addition, increasing financial dollarization was instrumental for CBE's loss of monetary control. The conduct of monetary policy collapsed when the gradual unlock of deposits triggered a new round of deposit runs as sucres demand plummeted from mid-1999 onward, in light of a large expected exchange rate depreciation. Toward end-1999, despite the sharp increase in CBE's interest rates, sterilizing LOLR assistance to banks and the increasing deliver of the government's blanket guarantee became ineffective. First, because the required increase in interest rate consistent with the expected depreciation of the sucre would have made nothing but to harm even more economic activity and illiquid banks. And second, because the combination of large CBE's securities in circulation and increasing interest rates, resulted on new OMOs that did not even sufficiently compensate interest payments on existing CBE's paper, leading the CBE to loose control of monetary policy (Figure 26).

The final collapse of monetary policy took Ecuador to the brink of hyperinflation encouraging the market to take refuge in the U.S. dollar as a safe store of value until the government officially adopted the dollar as a legal tender in January 2000. Exchange rate depreciation picked up as it doubled in the last four months of 1999 in anticipation to a potential collapse of the sucre. As a result, monthly inflation accelerated to more than 5 percent average in the fourth quarter, which then climbed to more than 14 percent in January 2000, in a run-up to a hyperinflation, which, in the end, never materialized because the government announced the formal dollarization of the economy.

\section{CONCLUding REMARKS}

Ecuador's full-blown financial crisis yields important lessons applicable to future financial crises. The lessons extracted from this paper are predicated on the mutually reinforcing and amplifying effects of chronic institutional weaknesses, ingrained fiscal rigidities, and high financial dollarization that characterized this crisis. Although these factors were not concurrent in most countries, or at least they are not as intense as they were in Ecuador, recent crises in Latin America show that they may be-to a certain extent-relevant to explaining the dynamics of banking crises. As an example, the multiplicity of events that occurred during the late-1990s banking crisis in Ecuador (bank holiday, deposit freeze, public debt default, and currency crash) also occurred during the subsequent full-fledged banking crises in Argentina and Uruguay. 
A first lesson to be drawn is that institutions matter and, hence, their strengthening should be a top priority in countries' reform agendas. Not having an appropriate legal and institutional framework for preventing banking crises makes a country more vulnerable to financial crises, in particular when it is exposed to real and financial shocks. When the crisis erupts, the resulting costs tend to be higher than if strong institutions and governance are in place to contain the crisis at an early stage. In the absence of these conditions-and when fiscal adjustment is necessary but also absent-monetary policy will be the only instrument of policy response while governments elaborate and pass legal reforms to make crisis management more effective. Passing a legal reform in the middle of the crisis, however, may be subject to protracted political negotiations. Meanwhile, the prolonged financial assistance provided to impaired banks leads to broad macroeconomic instability and to further banking deterioration. What makes the Ecuadoran episode unusual is that, even after having in place appropriate legal arrangements to manage the financial crisis, the government continued monetizing the crisis, which ended up causing the collapse of the currency and the banking system. This seeming paradox is, to a great extent, explained by political economy factors as vested interests managed to bring about an unequal distribution of the costs of the crisis throughout the society, thereby contributing to the collapse of public finances.

Second, the absence of fiscal adjustment during periods of financial crisis accelerates macroeconomic deterioration, in particular when public finances are weak, thereby increasing the cost of the crisis. Failing to align the stance of fiscal policy with the worsening macro financial trend associated with the banking crisis leads to a deterioration of market sentiment, both domestically and in the international community. As a result, interest rates pick up following the restriction of external finance and the increase in country-risk indicators triggering further instability in banks' liabilities. The Ecuadoran experience illustrates, in addition, the risks of exacting a tax on financial transactions when the banking system faces a liquidity crunch. Although it is probably more efficient than increasing other taxes from a revenue-collection standpoint, adopting a-sufficiently high-financial tax in the midst of a systemic liquidity shortfall may create a deadly cocktail, as market participants will try to circumvent the payment of the tax by switching these transactions outside the financial system, thereby leading to deposit withdrawals from the banking system. The Ecuadoran crisis also shows how a blanket guarantee can fail to restore the stability of bank liabilities as markets anticipate the government's inability to pay deposits due to fiscal shortages. As a result, bank failures multiply and the blanket guarantee boomerangs exacting a grievous toll and ultimately contributing to a fiscal crisis.

Third, confronting a banking crisis using only monetary policy is not sustainable for more than a short period, since it is conducive to macroeconomic instability and to additional market uncertainty. The financial crisis in Ecuador shows that failing to apply bankresolution instruments at an early stage of the crisis and to tighten fiscal policy as needed, leaves monetary policy as the only-and an ineffective-line of defense against financial crises. A persistent and large printing of money stemming from central banks' emergency assistance may result in monetary policy becoming totally fruitless. In particular, as the crisis reaches systemic proportions, interest rates required to mop up liquidity are so high that they severely damage the rest of the economy, including the banking system. In addition, the 
continuous printing of money, in an environment of high financial dollarization, invariably leads to a currency crash.

Fourth, financial dollarization may be a source of vulnerability in the financial system, in particular if financial institutions are already in a weak condition and macroeconomic fundamentals are not in place. Although in normal times financial dollarization is not intrinsically bad, in the event of a banking crisis - as occurred in Ecuador-deposit withdrawals will more likely translate into foreign currency given that financial contracts and the supply of dollar-based financial services are more likely to be at hand. If the central bank cannot inject international reserves as needed to prevent the weakening of the domestic currency, the resulting depreciation will invariably erode the quality of banks' assets and, hence, their solvency. Under these circumstances, market participants may anticipate further banking system problems, which may trigger deposit outflows as the market comes to fear that dollar deposits in the financial system may not be fully convertible anymore.

Fifth, increasing financial dollarization, in combination with a low and decreasing trend of the central bank's international reserves, undermines the credibility of financial safety nets, thereby restricting the government and central bank's ability to manage banking crises effectively. The Ecuadoran experience confirms that heightened financial dollarization-that exceeds the amount of central bank's international reserves-inflicts a further loss of credibility to the blanket guarantee and to central bank's capacity to serve as lender of last resort. The presumption that under high financial dollarization and low international reserves the financial safety net provides only a partial buffer to bank depositors can make deposit withdrawals self-sustained, thereby making crises more difficult to handle.

Finally, the modality of ending a bank holiday is crucial, since it may exacerbate the costs of the crisis. Adopting a bank holiday should be a last resort, given the generalized loss of confidence it spreads throughout the market. Furthermore, once this extreme decision has been adopted, opening all banks at the end of the bank holiday, regardless of their viabilityas in Ecuador-will leave the government without any alternative but to adopt a severe freezing of deposits to avoid general contagion. In addition to producing an enduring and generalized loss of confidence in banks, a widespread freeze of deposits encourages social unrest and legal claims, which may force a premature unlocking of deposits that may lead to a potential pickup in withdrawals. Alternatively, maintaining closed all unviable banks after the bank holiday, if accompanied by credible macroeconomic policies and international financial support, will limit the scope — and may even avoid — a freezing of deposits, paving the way for a gradual restoration of confidence in the financial system. 


\section{INSTITUTIONAL WEAKNESSES AND THE FinANCIAL SECTOR}

This appendix addresses institutional weaknesses in Ecuador's financial sector and stresses their relevance in contributing to the 1990s financial crisis. In particular, it reviews institutional insights that featured the functioning of the banking system during the 1990s and the legal framework that underpinned government decisions when the financial crisis materialized.

Consistent with a history of political instability, Ecuador has a long record of weak institutions. During the second half of the 1990s - prior to the outbreak of the banking crisis-political instability became critical when five presidents governed Ecuador between 1995 and 1998, and hence, over that same interval Ecuadorans watched seven finance ministers come and go. Political instability also brought in permanent changes to legislation, including the enactment of a new constitution in 1998 - the second one in a 20 years period-reflecting to a great extent short-term political economy considerations. ${ }^{48}$

Institutional weaknesses are associated to a great extent to the strong fragmentation of the country, which is conducive to differentiated behavioral patterns (see Box 1). ${ }^{49}$ As a result of this fragmentation there is a bipolar development of the country around Quito, the capital and center of the political administration, and Guayaquil, the largest city and the economic core, which harbored until the banking crisis the largest share of the country's financial system. Both cities - which influence the Sierra and the Coast, the two main regions of the countryhold distinct and, at times, opposed views about the route of development that Ecuador must follow. ${ }^{50}$ Under this fragmentation, and contrary to what is observed in modern democracies, social and economic demands are channeled intensively via social organizations since they supersede in a great extent the role of political parties. Such social organizations include the private enterprise associations and local governments in the Coast and public sector unions and indigenous groups in the Sierra. These local and regional groups have deployed great energy to defend or seek rents and political power-to a great extent associated to the country's oil wealth-many times at the expense of the rest of the population. ${ }^{51}$

\footnotetext{
${ }^{48}$ See Arteta and Hurtado (2002), who addresses recent political and economic legal instability in Ecuador.

${ }^{49}$ See Alesina and others (2003) on the importance of ethnic, linguistic, and religious differences in explaining economic growth, the quality of institutions, and government policies.

${ }^{50}$ Ecuador's bipolar development seems to better fit the concept of "polarization” proposed by García-Montalvo and Reynal-Querol (2002), which they also find empirically, has an indirect negative effect on economic growth. Typically, polarization is maximized when there are two groups of equal size-like the Coast and the Sierra in Ecuador.

${ }^{51}$ The influence of ruling elites to funnel society's savings toward their own benefit is not an Ecuadoran exclusive feature as it has also been observed in other countries in the region (see Haber, 2002). Moreover, this is a subject of interest in relation to theories of financial development of countries (see for example Rajan and Zingales, 2003).
} 


\section{Box 1. Ecuador's Geographic, Ethnic, Political, and Economic Fragmentation}

Natural features — climate and resource endowment—divide Ecuador into three regions: the Pacific Coast, the Andean highlands (Sierra), and the Eastern region. The Sierra and the Coast is where over 95\% of the country's population lives, with the two largest cities, Quito in the Sierra and Guayaquil in the Coast, being the drivers of political and economic activity; the third region, the East, has progressed less, even though it harbors the country's greatest wealth-oil. Those two cities and their metropolitan areas absorb more than 50 percent of the nation's population and exert a heavy influence over the rest of the country.

Though this geographic fragmentation is not matched by differences in religion there is some small linguistic variance and, most notably, differences in the racial makeup of the population. Ethnic differences stem from the large indigenous population living exclusively in the Sierra and the Eastern region, which have exerted increasing influence on political and economic decisions over the 1990s.

The Coast and the Sierra also exhibit different political views, clearly manifested via their voting track records. During the 1990s, the Coast has banded around two populist political parties with a liberal-in the economic sense-approach that speak mainly for business, private organizations, and regional interests. Neither of those political forces has made inroads in the Sierra, where politics is dominated by two other parties with a more ideological root that advocate a more intensive State involvement in the economy. As a result, Ecuadoran political parties have only a regional rather than a national range. This political fracture has been mirrored at the various levels of public representation, including the executive branch. For instance, with a single exception, Ecuador's ten presidents since its return to democracy in 1979 have come alternately from the Coast and from the Sierra. This was not so much because of any rotation agreement, but the result of a rival competition between the two regions. This is illustrated by the regional polarization of voter preferences in the 1998 legislative elections, particularly in the Coast, where the two representative parties captured close to 90 percent of the seats, while in the Sierra representative political parties of the same region won 76 percent of the seats.

Because the two regions' climates are so different, their patterns of economic activity are distinct as well. While the Coast predominantly produces commodities (bananas, coffee, cacao, and shrimp) for the world market, the Sierra produces mostly for domestic consumption, with a handful of exceptions such as fresh flowers. As a result, terms of trade deterioration-via a drop in commodity prices-has affected the Coast most. In addition, the Coast has been harder hit by the natural disasters that Ecuador has weathered in recent decades (El Niño floods in 1982-83 and 1997-98). The most recent round of destruction did much to set in motion the late 1990s financial crisis, impacting chiefly banks in the Coast region. From an economic policy standpoint, policy decisions tend to affect the two regions differently, sometimes in opposite ways as a result of their distinct pattern of production. For instance, the behavior of the real exchange rate has tended to favor one region over the other, i.e., a real depreciation benefits the Coast's larger export base, and vice versa. In general, an outwardoriented growth strategy is of greater benefit to the Coast, while inward-oriented policies and a more intensive involvement of the State in the economy have been more beneficial for the Sierra-through the expansion of employment. Consistent with its outward-oriented production, the Coast held the majority of foreign lines of credit, and hence, its banks were generally more exposed to financial external shocks. 
Institutional weaknesses are particularly relevant in the financial sector and, as a result, Ecuador has relied on fragile institutions to provide market regulation and stabilization. The legislation approved during the first half of the 1990s proved to be instrumental in shaping the late-1990s banking crisis and its aftermath as they severely restricted government's ability to respond timely and efficiently to tackle the banking crisis.

\section{A. Prudential Supervision and Bank-Resolution Instruments}

Prior to the financial crisis, the SBS's powers were primarily aimed at demanding corrections to financial institutions should capital deficiencies arise; however, for the most part corrective actions were triggered in scenarios where the damage on bank balance sheets was already irreversible. ${ }^{52}$ The supervision of financial institutions' featured compliancechecking practices rather than risk-oriented procedures. No corrective measures were envisaged to curtail excessive risk-taking by financial intermediaries at an early stage, to cope, for example, with situations in which a bank was taking undue risks from currency or maturity mismatches, or in the event that a bank was paying deposit interest rates far in excess of market returns. In the absence of proper and effective early remedial actions, banking authorities were likely to end up confronting banking crisis rather than preventing their occurrence.

In addition, the enforcement of law and regulations was feeble. Even existing regulations were not always readily enforced, in part as a result of the SBS lack of political independence-five superintendent of banks were in functions between 1995 and 1998, before the outbreak of the banking crisis-and the absence of legal protection for regulators. In this connection, it is not surprising that international audit firms that assessed the soundness of the Ecuadoran banking system-on a consolidated basis-following the freeze of deposits in March 1999, came across a number of institutions severely insolvent, a situation that had not been reported by the SBS beforehand.

Another major problem of the LFSI was that it did not set the stage for an efficient handling of banks distress and crises, and moreover, it hindered governments' capacity to confront banking crises. Once banks illiquidity or insolvency was irreversible, there were two basic avenues under the law for banking resolution: (i) the continuous provision of financial assistance from the $\mathrm{CBE}$ - until the troubled bank exhausted assets that were eligible to submit as collateral to the $\mathrm{CBE}$ in exchange for the emergency assistance; and (ii) to grant a subordinated loan either from the CBE or from other commercial banks. Moral hazard problems and monetary policy disarticulation would come into play when the CBE provide large amount of funds, which eventually would trigger broad macroeconomic instability and

\footnotetext{
${ }^{52}$ De la Torre (1997) notes that the legislation brought in with the 1994 reform gave Ecuador a "Chilean style" legal framework for a non-Chilean environment, meaning that the reforms presupposed the existence of stable macroeconomic conditions and high quality prudential supervision of financial intermediaries — conditions that were not observed in Ecuador.
} 
therefore a deeper banking crisis. The same implications are valid under the second alternative since counting on commercial banks' subordinated loans was restricted only to idiosyncratic events. ${ }^{53}$ It goes without saying that having the central bank as owner of a commercial bank would deviate monetary policy from its main responsibilities, ${ }^{54}$ and may lead to monetary disruptions as well, in particular when dealing with a sizable financial institution.

Without legal basis to transfer deposits from the failing bank to a sound financial institution, the decision of closing a failing bank carried with it a high risk of contagion, and hence, it was only an option for very small institutions. In general, there was no provision in the law for splitting off the failing bank assets and liabilities and to transfer the "good bank" into a healthier institution under P\&A. This was in particular so because governments had no legal basis to put in money to facilitate P\&A, and hence to smooth market exit of troubled institutions, which would have been a less costly solution. Thus, the only alternative available to confront banking crises, other than simply providing abundant liquidity assistance, was the closure of the impaired bank. However, given the slow pace of payments to small guaranteed depositors and the lack of coverage for medium and large depositors as envisaged in the existing financial safety net, bank closures will invariably be traumatic, thereby creating uncertainty in the market about the safety of deposits and thereby triggering contagion.

\section{B. The Central Bank}

The 1992 reform to the central bank charter granted operational autonomy for the conduct of monetary policy, thereby allowing the CBE to focus exclusively in abating inflation. Operational autonomy relied on two pillars: (i) independence to choose policy instruments (instruments independence) to achieve policy goals; and (ii) ruling out fiscal deficit financing, not even to cope with seasonal shortages.

Nonetheless, the reform failed to provide political autonomy to the CBE as it maintained private sector dominance at the CBE Board level. Until 1998, two of the seven members of the Monetary Board (the central bank board) were appointed by the private business associations (one from each of the two main regions of the country) and another member of the Board was appointed directly by the commercial bankers association. In addition, the Monetary Board chairman - a direct presidential appointee-was often an active commercial banker. The government also appointed directly two other representatives to the CBE Board for a concurrent term in office, who could also be bank administrators or shareholders. The seventh member of the Monetary Board was the Minister of Finance, who also had voting

\footnotetext{
${ }^{53}$ In a systemic crisis sound banks will rather prefer to preserve their own liquidity than to lend to an impaired bank in anticipation of potential deeper liquidity problems.

${ }^{54}$ The handling of the 1995 Banco Continental debacle is a case in point.
} 
rights. With such a board structure, there was a potential for conflicts of interest when critical decisions about monetary, exchange rate, and financial policy issues were necessary, as it indeed happened during the 1980s (see Box 2). Institutional instability was another feature of the CBE that signaled a lack of political autonomy. During the 1990s, the average turnover of central bank governors was one per year, and was the highest in Latin America together with Brazil. $^{55}$

To correct the lack of political autonomy of the CBE, the 1998 Constitution excluded from the Central Bank Board all private sector and government representatives and replaced them with directors nominated by the President of the Republic and appointed by Congress. While the constitutional reform indeed built the legal blocks for central bank's political independence, it entered into effect while the banking crisis was unfolding, and thus, the monetization of the banking crisis overrode the central bank's scope to conduct an autonomous monetary policy and to build up credibility.

In light of these institutional shortcomings one can readily imagine how difficult it was to keep monetary policy management stable and for the SBS to assure continuity and high quality in monitoring financial intermediaries. This was a particularly grave concern in an environment of financial liberalization and rapid financial sector growth as observed in Ecuador over the 1990s.

\section{Financial Safety Net}

The early 1990s new legislation and the subsequent reforms built the blocks of a financial safety net. The 1992 CBE Law entrusted the CBE with broad powers to provide assistance to both illiquid and insolvent banks, thereby creating conditions for large monetary expansion. Liquidity assistance was authorized up to two times the bank's equity, which was provided under market conditions in exchange for collateral to be valued by the CBE in excess of the amount of the emergency loan. ${ }^{56}$ The CBE was also legally entrusted to provide "stabilization loans," which should be understood, for all practical purposes, as a solvency loan. "Stabilization loans" were provided at softer financial conditions, i.e. slightly lower interest rates and longer maturity (up to 270 days) than liquidity loans, on the condition that the problem bank should implement a stabilization plan elaborated by the SBS and approved by the CBE. In addition, the CBE was also authorized to recycle liquidity in the interbank market in order to help banks facing liquidity shortages. These resources were channeled at

\footnotetext{
${ }^{55}$ See Jácome (2003). By way of comparison, Ecuador's neighbors Colombia and Peru had only two central bank governors each between 1990 and 2000.

${ }^{56}$ Liquidity assistance was lent at market rates up to 180 days, in exchange for real or financial assets of the impaired bank.

${ }^{57}$ Furthermore, the 1998 Constitution was explicit in authorizing the CBE to assist to banks that were experiencing solvency problems "until the State has suitable legal instruments for managing financial crises."
} 
higher than market interest rates through an automatic liquidity window. Loans were intermediated overnight and borrower banks had access using government securities as collateral, which were marked to market by the CBE. Thus, legal provisions governing LOLR facilities undermined financial market discipline and encouraged a deep involvement of the CBE in banking crises.

The CBE was also entitled to honor a limited guarantee of deposits in the event of the closure of a bank, exacerbating central bank's involvement in banking crises and creating another source of monetization. ${ }^{58}$ Depositors who had money in a failing bank stood to receive payments in sucres roughly equivalent to US $\$ 8,000$ for both domestic and foreign currency deposits. ${ }^{59}$ Since the CBE was expected to deliver the deposit guarantee in exchange for qualified assets of the closed bank, this payout will generally be a very slow process, requiring cumbersome operational and administrative formalities to fulfill legal requirements. In turn, depositors holding larger balances could not get back their money-in excess to that amount - until the bank assets had been liquidated, and in accordance with the legally prescribed order of seniority of claims on those assets. As the liquidation of closed bank assets took years to materialize, and given that large depositors were bound to not recover their savings — or probably only a minimum amount — the closure of a failing bank would inevitably trigger a wave of contagion and runs on other financial institutions.

\footnotetext{
${ }^{58}$ While a deposit insurance mechanism had been recently approved by Congress, it was still waiting to be enacted by the executive branch when the banking crisis erupted.

${ }^{59}$ The deposit guarantee coverage varied as it was tied to an inflation-indexed unit. Expressed in dollars, that value depended on the performance of the real exchange rate.
} 


\section{Box 2. Recent History of Private Sector and Bank Bailouts Using Public Funds}

During the early 1980s, the increase in the country's external debt and its service-associated to the swift increase in world interest rates- spawned a rapid devaluation of the sucre in the context of the regional debt crisis. As a result, both public and private sectors found increasing hurdles to honor their external obligations. To cope with an imminent banking crisis; the Monetary Board authorized the Central Bank of Ecuador (CBE) to convert banks' foreign currency obligations into sucres. Specifically, the CBE assumed the foreign currency debt of commercial banks and simultaneously acquired a claim on sucres on commercial banks. The CBE lend them sucres at long term and preferential interest rates (the so-called "sucretization" of debt), charging a fee to cover the future exchange rate adjustment. Commercial banks were then required to pass this benefit on to their debtors, thereby restructuring borrower liabilities. As a reslut, commercial banks restored the quality of their assets and the value of their equity. The exchange risk fee was fixed in 1984 when the country adopted a fixed exchange rate regime, but its flexibility was not reestablished in 1986 when the exchange rate was allowed to float and the sucre dramatically fell. The CBE thus amassed huge losses, widening quasi fiscal deficits in the process. Despite the financial support provided by the CBE, a number of small financial institutions were liquidated in the latter half of the 1980s.

In 1988 the Monetary Board granted commercial banks a new subsidy as they were authorized to buy external public debt in the secondary market at a steep discount-Ecuador had defaulted on its external debt in 1987-which was then bought by the CBE at face value. Profits from these transactions were expected to be used to cover liabilities with the CBE and to bolster commercial banks equity. Samaniego and Villafuerte (1997) calculate the cost of this assistance at over 100 percent of the borrowing institutions' equity, an amount equivalent to 2.4 percent of GDP. Thereafter the CBE delivered additional support to ailing banks by assuming real assets to pay back their CBE borrowings and by way of extraordinary loans (one-year repayment term with six months' grace) to cancel overdrafts at the CBE, pay off existing obligations, and restructure non-performing loans.

The injection of significant amounts of money by the CBE boosted macroeconomic instability and triggered inflationary pressures. In 1988, high monetization led to a rapid depreciation of the sucre, accompanied by a surge in inflation that reached a 50 percent annual rate and persisted up to 1992. Consequently, society at large ended up paying this subsidy. In addition, as the CBE shouldered financial system's losses, its capital eroded, with no compensation from the government at the outset, despite the quasi fiscal nature of these operations.

After the new central bank charter was passed into law in 1992, the CBE continued to have broad powers as lender of last resort (LOLR), with open-ended emergency lending authority to help banks manage liquidity crunches and even solvency crises. The law also authorized the CBE to pay out a limited deposit guarantee-calculated using an indexed unit of account—in the event of closure and liquidation of a financial institution.

Repeated CBE-funded bailouts of problem banks created an environment of moral hazard, since there was no incentive for banks to carefully gauge their risks, or for depositors to limit their exposure, as they knew that their money was implicitly protected. Even the government felt that it was covered as CBE's resources were available to finance the cost of banking problems without any fiscal compensation. 


\section{REFERENCES}

Acemoglu, D., S. Johnson, J. Robinson, and Y. Thaicharoen, 2002, "Institutional Causes, Macroeconomic Symptoms: Volatility, Crises, and Growth. Mimeo (August).

Alesina, A., A. Devleeschauwer, W. Easterly, S. Kurlat, and R. Wacziarg, 2003, "Fractionalization," NBER Working Paper No. 9411, Cambridge, Massachusetts, (June).

Arteta, C., 2003, "Are Financially Dollarized Countries More Prone to Costly Crises?," International Finance Discussion Papers, No. 763 (Washington: Board of Governors of the Federal Reserve System).

Arteta, G., and O. Hurtado, 2002, "Political Economy of Ecuador: The Quandary of Governance and Economic Development," unpublished (May).

Banco Central del Ecuador, 1996, "El Caso del Grupo Conticorp: Aumento de Capital Cuestionado y Presunto Beneficio a Empresas Relacionadas y a Accionistas, a Expensas de los Depositantes."

Beckerman, P., 2002, "Longer-Term Origins of Ecuador's "Predollarization" Crisis," in P. Beckerman and A. Solimano Eds., Crisis and Dollarization in Ecuador. (Washington: The World Bank).

Cardoso, E., and R. Rigobon, 1999, "The Macroeconomics of Undoing a Deposit Freeze: What Ecuador Can Learn from Argentina and Brazil," unpublished (July).

Collyns, C., and R. Kincaid, 2003, "Managing Financial Crises: Recent Experiences and Lessons from Latin America," Occasional Paper No. 217 (Washington: International Monetary Fund).

Das, U., and M. Quintyn, 2002, "Crisis Prevention and Crisis Management: The Role of Regulatory Governance," IMF Working Paper WP/02/163 (Washington: International Monetary Fund).

De la Torre, A., 1997, "El Manejo de Crisis Bancarias: El Marco Legal Ecuatoriano y Posibles Reformas," Serie: Temas de Economía y Política, No. 3, Corporación de Estudios para el Desarrollo, CORDES, Quito, Ecuador.

, R. García, and Y. Mascaró, 2002, “Financial Meltdown: Ecuador’s Banking and Currency Crises of the Late 1990s, unpublished.

De Nicoló, G., P. Honohan, and A. Ize, 2003, "Dollarization of the Banking System: Good or Bad?, IMF Working Paper WP/03/146 (Washington: International Monetary Fund). 
Dress, B., and C. Pazarbaşioğlu, 1998, “The Nordic Banking Crises: Pitfalls in Financial Liberalization? Occasional Paper No. 161 (Washington: International Monetary Fund).

Enoch, C., B. Baldwin, O. Frécaut, and A. Kovanen, 2001, "Indonesia: Anatomy of a Banking Crisis. Two Years of Living Dangerously 1997-99," IMF Working Paper WP/01/52 (Washington: International Monetary Fund).

Fischer, S., 2001, "Ecuador and the International Monetary Fund," in A. Alesina and R. Barro Eds., Currency Unions, Hoover Institution Press, Stanford, California.

Garcia, G., 2000, “Deposit Insurance: Actual and Good Practices,” Occasional Paper No. 197 (Washington: International Monetary Fund).

García-Montalvo, J., and M. Reynal-Querol, 2002, "Why Ethnic Fractionalization? Polarization, Ethnic Conflict, and Growth.” PRPES No. 17 Working Paper, Harvard University.

Haber, S., 2002, Crony Capitalism and Economic Growth in Latin America: Theory and Evidence, Hoover Institution Press, Stanford, California.

Hausmann, R., and L. Rojas-Suárez Eds., 1996, Banking Crises in Latin America, (Washington: Inter-American Development Bank).

He, D., and S. Seelig, 2000, "Deposit Transfer and Payoff in Bank Closures," MAE Technical Note TN/00/3, (Washington: International Monetary Fund).

Hemming, R., M. Kell, and A. Schimmelpfennig, 2003, "Fiscal Vulnerability and Financial Crises in Emerging Market Economies," Occasional Paper No. 218 (Washington: International Monetary Fund).

Hoelscher, D., and M. Quintyn, 2003, "Managing Banking Crises," Occasional Paper No. 224 (Washington: International Monetary Fund).

Hurtado, O., 1997, El Poder Político en el Ecuador, Editorial Planeta, Quito.

Ingves, S., and G. Lind, 1996, “The Management of the Bank Crisis in Retrospect," Quarterly Review Sveriges Riksbank (Sweden), No. 1.

Ingves, S., and M. Moretti, 2003, "Banking Failures in Countries Dependent on a Foreign Currency," Paper presented at the workshop on Individual Failures of Large BanksHow to Avoid Systemic Crises?, Stockholm, September 11-12, 2003.

Ize, A., and E. Levy-Yeyati, 2003, "Financial Dollarization," Journal of International Economics, Vol. 59, pp. 323-47. 
Jácome, L.I., 2003, "Independencia Legal de la Banca Central en América Latina e Inflación,” El Trimestre Económico, No. 280, Octubre-Diciembre, México D.F.

Kirilenko, A., and V. Perry, 2003, "Bank Debit Taxes: Productivity vs. Financial Disintermediation," unpublished.

Lindgren, C-J., T. Baliño, C. Enoch, A-M. Gulde, M. Quintyn, and L. Teo, 1999, "Financial Sector Crisis and Restructuring: Lessons from Asia," Occasional Paper No. 188 (Washington: International Monetary Fund).

Patiño, M.L., 2001, "Lessons from the Financial Crisis in Ecuador in 1999," Journal of International Banking Regulation, Vol. 3 No. 1, pp. 37-70.

Rajan, R., and L. Zingales, 2003, “The Great Reversals: The Politics of Financial Development in the Twentieth Century," Journal of Financial Economics, No 69, pp. 5-50.

Rodrik, D., A. Subramanian, and F. Trebbi, 2002, "Institutions Rule: The Primacy of Institutions over Geography and Integration in Economic Development," NBER Working Paper 9305 (October)

Samaniego, P., and M. Villafuerte, 1997, "Los Bancos Centrales y la Administración de Crisis Financieras: Teoría, Experiencia Internacional y el Caso Ecuatoriano," Cuestiones Ecoómincas, No. 32, Banco Central del Ecuador, Quito, Ecuador.

Sundararajan, V., and T. Baliño, eds, 1991, Banking Crises: Cases and Issues (Washington: International Monetary Fund). 